\title{
Iconografía del Formativo Tardío del norte de Chile. Propuesta de definición e interpretación basada en imágenes textiles y otros medios
}

Helena Horta T. ${ }^{1}$

\section{RESUMEN}

Este trabajo aborda el análisis iconográfico del Período Formativo del norte de Chile (ca. 1300 AC-600 DC); tomando como base imágenes de piezas textiles y complementando la información con imágenes de otros soportes (arte rupestre, geoglifos, láminas de oro y cestería) se intenta definir los elementos propios del universo iconográfico formativo, traspasando los límites del ámbito estrictamente textil. Se ha procurado obtener la mayor conjunción posible de imágenes, de manera de reunir información visual suficientemente sólida como para: a) proponer la existencia de un horizonte iconográfico propio de la fase tardía del Formativo; b) definir sus elementos constituyentes; c) vincularlo a los desarrollos surperuanos y altiplánicos. Entre los temas iconográficos planteados aquí para el Formativo Tardío figura el Personaje Frontal de Cabeza Radiada, el cual constituye un icono con atributos específicos y bien definidos; en relación con él se plantea la posibilidad de que quizás nos encontremos frente a una manifestación local (propia de los Valles Occidentales y de la Circumpuna) del ya clásico tema central de la iconografía de las culturas altoandinas Pukara, Tiwanaku y Wari: el "Personaje Frontal con Cetros".

Palabras claves: iconografía - Período Formativo - textil prehispánico - Personaje Frontal de Cabeza Radiada.

\section{ABSTRACT}

This paper attempts an iconographic analysis of the Formative Period in northern Chile (ca. 1300 BC to AD 600), drawing primarily on images found in textiles, but also on images depicted in rock art, geoglyphs, gold laminae and basketry. This enables to attempt a definition of elements belonging to the Formative iconographic universe, beyond the strict limits of the textile field. The large body of images we have assembles provides visual information that is sufficiently solid to: a) outline the existence of an iconographic horizon characteristic of the late phase of the Formative; b) define its constituent elements, and; c) connect it to south-Peruvian and altiplano developments. The Frontal Figure with Radiate Head is one of the iconographic themes we consider for the Late Formative, as an icon with specific and well-defined attributes. These suggest it might well be a local manifestation (i. e. Valles Occidentales and the Circumpuna subareas) of the classic central iconographic theme of the Pukara, Tiwanaku and Wari cultures of the High Andes: the "Front-facing
Staff-bearing Deity”.

Key words: iconography - Formative Period - prehispanic textiles - Frontal Figure with Radiate Head.

Recibido: mayo 2004. Manuscrito revisado aceptado: julio 2004.

\section{Introducción}

En la prehistoria del extremo norte de Chile el Período Formativo (1300 AC-600 DC) corresponde a uno de los estadios del desarrollo cultural prehispánico que más ha sido objeto de debate y foco de discusiones conceptuales (Schiappacasse y Niemeyer 1963, 1969; Dauelsberg 1963, 1985; Focacci y Erices 1972/73; Núñez y Moragas 1977; Núñez y Dillehay 1978; Santoro 1981; Moragas 1982; Muñoz 1983a, 1983b, 1987; Núñez 1992; entre otros). ${ }^{2}$ Este hecho no es casual, puesto que en este período acontecen profundas transformaciones al interior de la sociedad.

Las evidencias arqueológicas nos permiten observar, por una parte, la cristalización de una serie de importantes innovaciones tecnológicas que se venían gestando como procesos de larga data, tales como la utilización de la arcilla y las fibras vegetales y animales, que devienen en el uso consolidado de la cerámica y la textilería, respectivamente (Rivera et al. 1974; Santoro 1980; Ulloa 1982; Santoro y Ulloa 1985; Muñoz 1989; Muñoz et al. 1991). La información arqueológica referida también ha permitido detectar cambios sustantivos en relación con las costumbres fune-

Sociedad Chilena de Arqueología, Casilla 787, Santiago, CHILE. Email: hhortat@tie.cl

2 El período se divide en Formativo Temprano (Fase Azapa: 1300 AC-560 AC) con base en los contextos de los sitios habitacionales Azapa-71 y Azapa-14 (Santoro 1981) y Formativo Tardío (Fase Alto Ramírez: 500 AC-600 DC; Muñoz 1980, 1983a, 1983b, 1987). 
rarias que se practicaban desde tiempos arcaicos (Cultura Chinchorro 6000-2100 AC): en este lapso se lleva a cabo el traspaso definitivo del modelo de cuerpos extendidos y envueltos en esteras de fibra vegetal, al modelo de cuerpos flectados envueltos en esteras y en textiles, que luego son depositados entre camadas sucesivas de vegetales, tierra y argamasa (túmulos funerarios), o en fosas cavadas en la tierra a cierta profundidad.

Este hecho, por sí solo, planteó la idea de un posible arribo de población foránea (incluso en forma de colonias permanentes) a los Valles Occidentales del extremo norte de Chile, por parte de arqueólogos dedicados al estudio de la prehistoria del Area Centro Sur Andina (Rivera 1974, 1975, 1976, 1980, 1984, 1987, 1995; Rivera et al. 1995/96; Mujica 1985; Núñez 1970, 1971, 1976, 1982, 1984a y 1984b, 1989, 1992; Kolata 1993; Goldstein 1995/1996, entre otros). Dicho planteamiento también se basa en la observación del registro arqueológico de diversos sitios del Norte Grande, que delatan la aparición sin antecedentes previos del cultivo de ciertas plantas (maíz, quínoa, frijoles, junto al cultivo conocido localmente desde antaño de calabazas y algodón), así como del manejo aún muy limitado del metal (oro, plata, cobre).

Es así como hasta aquí el estudio del Período Formativo ha sido planteado permanentemente en función de la búsqueda del o los posibles orígenes de las nuevas influencias detectadas, y esto ha ocurrido tomando como base ciertas piezas textiles aisladas -entre otros elementos- que se destacaban en el conjunto textil por ser poseedoras de iconografía sugerente ("similar a") y, por lo mismo, con iconografía factible de ser vinculada a desarrollos culturales foráneos (Pukara, Chiripa, Wankarani, Tiwanaku, Nasca).

Surge entonces, en relación con el tema del origen de las comunidades formativas, la tesis de la proveniencia altiplánica circumtiticaca (fundamentalmente Pukara), tomando en consideración la iconografía de un número menor de textiles (tapicerías), gorros tubulares decorados con diseños escalerados y la presencia de aportes tecnológicos y patrones funerarios nuevos en el norte de Chile (Rivera 1976, 1980, 1987; Rivera et al. 1995/1996; Mujica 1985, 1991; Mujica et al. 1983; Muñoz 1995/96; Focacci y Erices 1972-73, 1980; Lumbreras 1981; Núñez 1976).
Básicamente, la crítica que formulo a estos planteamientos y que intentaré sustentar en este artículo es que no han contemplado el análisis de conjunto de la industria textil del período, descuidando la observación directa de sus diversos componentes, y que tampoco se han basado en datos cuantificados acerca de la frecuencia de determinados textiles en el registro arqueológico local. En consecuencia, tomando como base la definición estilística de ciertos textiles aislados se ha intentado extrapolar pretendidas influencias a un desarrollo cultural local de casi 2000 años, como veremos más adelante.

El proyecto, del cual es resultado este artículo, ${ }^{3}$ se planteó como instrumento metodológico el análisis del conjunto de los textiles de diversos sitios con material cultural catalogado como formativo, tanto de la Subárea de Valles Occidentales (Arica, Camarones y Tarapacá) como de la Circumpuneña (río Loa y San Pedro de Atacama). De esta forma, ha sido posible detectar con propiedad lo que es intrusivo en este conjunto textil específico, discernir entre lo local y lo foráneo presente en él, además de lograr reconocer las raíces de la textilería local y sus imbricaciones con tradiciones textiles no locales.

Al mismo tiempo, el registro textil arqueológico y bibliográfico efectuado por Agüero y Cases (2004) ha permitido establecer los elementos característicos de la vestimenta del Período Formativo, presente en los ajuares mortuorios; aún cuando dicho registro está constituido por hallazgos de una extensa área (I y II Región de Chile), y presenta naturalmente algunos rasgos regionales propios, arroja también información muy precisa acerca de los elementos más frecuentes y masivos de la vestimenta funeraria. Estos son: gruesas mantas confeccionadas en ligamento torzal o tejidas a telar en faz de urdimbre; faldellines de haces de fibra vegetal o de pabilos de fibra de camélido en técnica de torzal; varios tipos de túnicas rectangulares en faz de urdimbre, entre las cuales encontramos monocromas simples, listadas en colores naturales y otras de mayor elaboración con una banda inferior en faz de trama; gorros (tubulares y hemisféricos) y bolsas (tubulares y

\footnotetext{
Esta investigación se realizó en el marco del Proyecto FONDECYT No 1990168: "Tejidos, alfarería y cementerios: El período Intermedio Temprano desde Quillagua, Loa Inferior".
} 
rectangulares) en técnica de malla o anillado; completan la lista los taparrabos tejidos en faz de urdimbre o en una combinación de faz de urdimbre y faz de trama, y las fajas-deformadoras de cráneos en faz de urdimbre o trenzadas (Agüero y Cases 2004; véanse también Chacama y Muñoz 1991; Núñez 1967; 1982).

En este artículo se aborda el análisis iconográfico de dichos textiles, observados en su conjunto; no obstante ello, en la búsqueda de analogías iconográficas al interior del período en estudio, hace ya tiempo surgieron elementos que captaron la atención de los investigadores, quienes destacaron similitudes iconográficas en otros soportes materiales, tales como geoglifos, petroglifos, láminas de oro y cestería. De esta manera, y basándome en todos estos elementos, el presente estudio se propone definir la iconografía del Formativo Tardío, determinar sus elementos estables e interpretarlos, así como establecer sus posibles focos de origen, de acuerdo con el análisis sistemático de sus imágenes.

De antemano, es necesario aclarar que la textilería de la fase temprana del Formativo está conformada por escasos tejidos decorados estructuralmente, pudiéndose señalar tan sólo algunas mínimas excepciones (fundamentalmente fajas-deformadoras de cráneos), en donde la técnica usada no va más allá que la alternancia de urdimbres de dos colores distintos, con el fin de obtener sencillos motivos geométricos ("peinecillo" o "línea segmentada"), o los casos de esteras tejidas en torzal con inclusión de bordados en colores (Focacci y Chacón 1989); en rigor, la decoración figurativa no aparece todavía en escena, en tanto medio de transmisión de ideas y conceptos, y su rol de embellecimiento de la prenda textil es aún incipiente. Es, por el contrario, en la fase tardía de este período (aproximadamente a partir del $500 \mathrm{AC}$ ), cuando junto con los diseños geométricos para tejidos anillados (Santoro 1980; Muñoz 1980, 1987) aparecen también los primeros diseños estructurados y de carácter figurativo; son estos motivos en conjunto, geométricos y figurativos los que guiarán nuestro análisis, y en los que se apoya este trabajo.

\section{Material textil estudiado}

Los cementerios que aportaron material para el registro textil fueron para el valle de Azapa (interior de Arica): Az-14 ( $\mathrm{n}=$ indeterminado de textiles), Az-70 (túmulo; n=64), Az-71 (n=indetermi- nado), Az-115 (n=8) y Az-122 (túmulo; n=17); para el valle costero de Camarones (100 km al sur de Arica): Cam-15 A y B ( $\mathrm{n}=55)$; para Pisagua (150 $\mathrm{km}$ al sur de Arica): Cementerio-D ( $\mathrm{n}=25)$; para la desembocadura del río Loa, en Caleta Huelén: CaH43 (túmulo; $n=8$ ); para el Loa Inferior, en Quillagua: Qui-84 ( $\mathrm{n}=36)$; para el Loa Medio: Topater-1 $(\mathrm{n}=99)$, y para los valles interiores de la Pampa del Tamarugal, Tarapacá-40 A y B (n=107) (Agüero y Cases 2004) (Figura 1). En conjunto, las colecciones provenientes de estos cementerios constituyen una muestra de 419 textiles. $^{4}$

Entre las manufacturas que se consolidan durante el Formativo -alcanzando al mismo tiempo notables niveles de sofisticación y belleza- se encuentran la cestería y la textilería. Esta última ya presenta una diversificación básica del universo textil en dos ramas paralelas que se mantendrán por siglos hasta la llegada de los españoles, consistente, por un lado, en textiles tejidos a telar y, por otro, en la confección de bolsas, gorros y redes en técnica de anillado, para los cuales no se necesita más instrumento que una aguja (de espina de cacto en este caso). De acuerdo con esto, procederemos a analizar por separado las características técnicas, formales y decorativas de uno y otro grupo. Del conjunto de prendas que componen la vestimenta de este período, sólo abordaremos el examen de aquellas túnicas, taparrabos, tapicerías sin forma identificable y bolsas que exhiben algún tipo de iconografía. Las mantas -cuyo rol es preponderante en el ajuar mortuorio Formativo- no serán consideradas, puesto que las soluciones decorativas aplicadas a ellas se reducen exclusivamente a listas, o también a diferencias de torsión en los hilados para conseguir efectos de textura y de afelpado.

\section{Tejidos a telar en técnica de tapicería}

\section{1) Túnicas}

Este conjunto textil está conformado fundamentalmente por túnicas rectangulares tejidas en faz de urdimbre, cuyo borde inferior presenta en ambas caras una banda horizontal en faz de trama (7-15 cm de ancho), que frecuentemente es

4 En el análisis de Agüero y Cases (2004) fueron considerados los contextos de los cementerios Az-70, Az-71 y Az122 para caracterizar la textilería formativa tardía del valle de Azapa (500 AC-500 DC). 


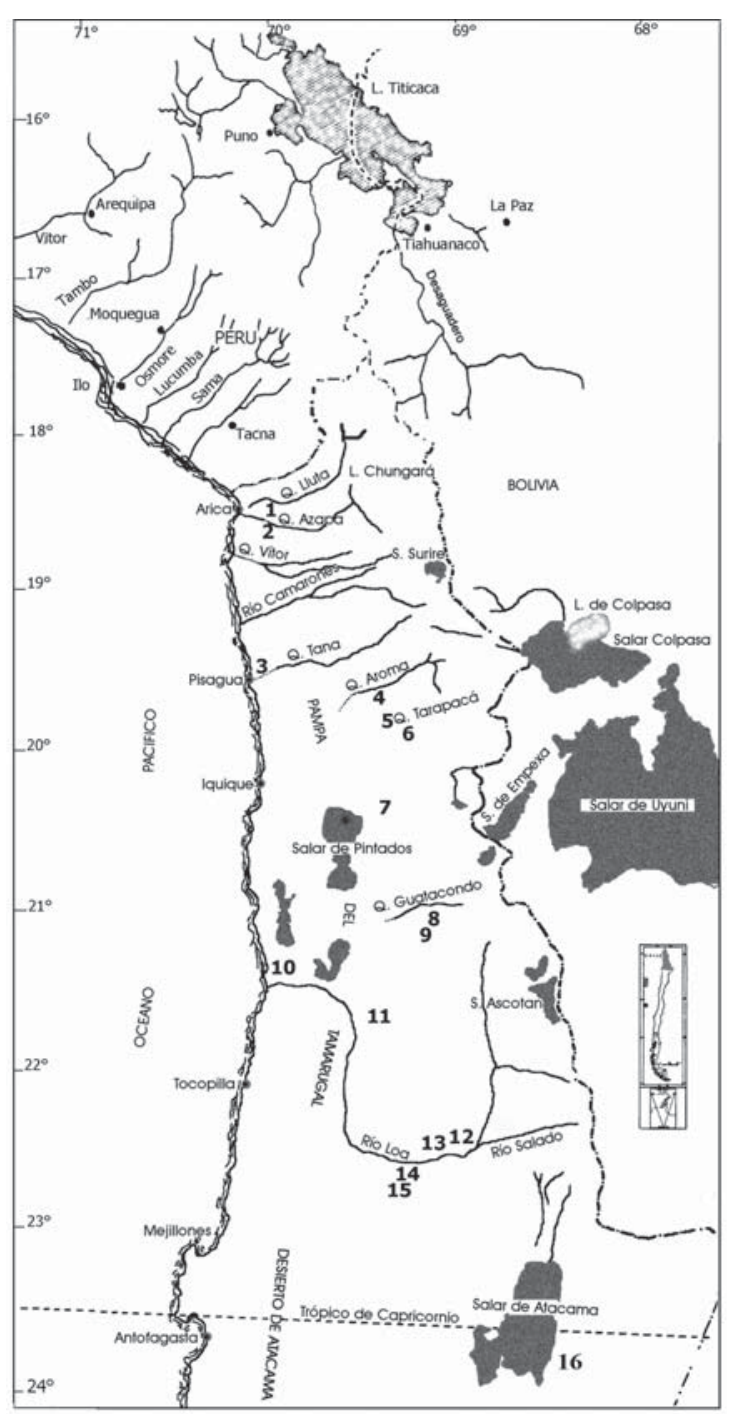

Figura 1. Sitios mencionados en el texto: 1) Az-14, 71 y 115; 2)Az-70 y 122; 3) Cam-15A y B, Pisagua; 4) Ariquilda; 5) Pircas; 6) Tarapacá-40; 7) Pica; 8) Guatacondo; 9) Tamentica; 10) Caleta Huelén; 11) Quillagua; 12) Chiu Chiu; 13) Chorrillos; 14) Calama; 15) Topater; 16) Tulan.

de un color diferente al del resto de la pieza, y que en ocasiones puede exhibir decoración figurativa y geométrica (Agüero y Cases 2004). ${ }^{5}$ De entre varias variantes, es un subgrupo el que presenta decoración figurativa en la banda inferior confeccionada en faz de trama con unio-

5 Este particular tipo de túnica ya había sido descrito por Ulloa (Rivera et al. 1974) en relación con los uncus del sitio costero de Arica, Playa Miller-7, pero sin entregar desgraciadamente información acerca del nivel de frecuencia que alcanzaba en el mismo. nes en tapicería entrelazada (interlocked tapestry). El nivel de frecuencia de la variante decorada es muy bajo, encontrándoselo referido al sitio Az-70, donde se lo observó en dos casos (piezas $\mathrm{n}^{\circ} 130 \mathrm{y} \mathrm{n}^{\circ} 122$, sin contexto), y en el caso del reporte reciente del arqueólogo Juan Chacama sobre un fragmento en todo semejante a los de Az-70, proveniente de los alrededores del control aduanero de Cuya, al interior del valle de Camarones (Figura 2 a y b).

Por el contrario, el nivel de frecuencia de la variante no decorada, vale decir, el de aquellas túnicas que sólo presentan una banda inferior en faz de trama de un color diferente al del resto de la túnica, es mucho mayor y de amplia dispersión en el Norte Grande (cinco ejemplares de Az-70; dos ejemplares de Cam-15; tres de Tarapacá-40; dos de Pisagua; cinco de Quillagua; 13 ejemplares de Topater, sumando un total de 30 túnicas de este tipo).

Tal como se puede observar en la Figura $2 \mathrm{a}$ y b, tanto la decoración de la pieza $\mathrm{n}^{\mathrm{o}} 130$-como la de Cuya, a pesar de su alto grado de fragmentación- está conformada por dos iconos diferentes dispuestos en tres módulos: en el centro una cabeza radiada en todo su perímetro, con boca y ojos enmarcados en rectángulos; a cada uno de sus costados un ser zoomorfo de cuerpo cuatripartito (cromáticamente), de brazos flectados hacia arriba terminados en tres dedos, mientras que la cabeza presenta ojos rectangulares y seis apéndices rectos. Otra particularidad de este ser es la conformación del tronco y las extremidades inferiores; en una primera aproximación a la imagen no es posible discernir más detalles que nos pudieran dar pistas acerca de su aparente identidad animal, pero más adelante veremos que existe una analogía que aporta datos en favor de su identificación como batracio.

Los rasgos comunes compartidos por la cabeza radiada y el zoomorfo de cuerpo cuatripartito son la división longitudinal que presentan, la cual divide el espacio interior de cada icono en dos mitades de diferente color (rojo oscuro y azul oscuro); en el caso del zoomorfo esta división es cuatripartita, y no bipartita como ocurre con la cabeza radiada. La composición es perfectamente simétrica, su estilo lineal y esquemático.

Por otro lado, hay que destacar la existencia de una bolsa en tapicería proveniente del mismo si- 


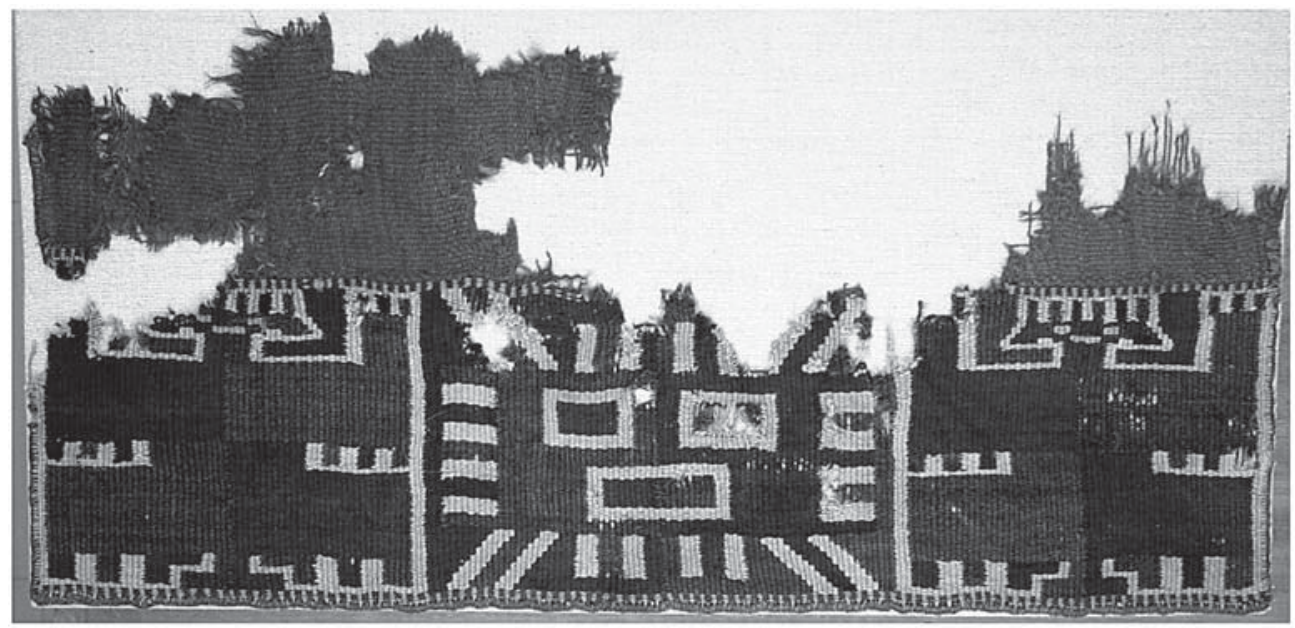

a

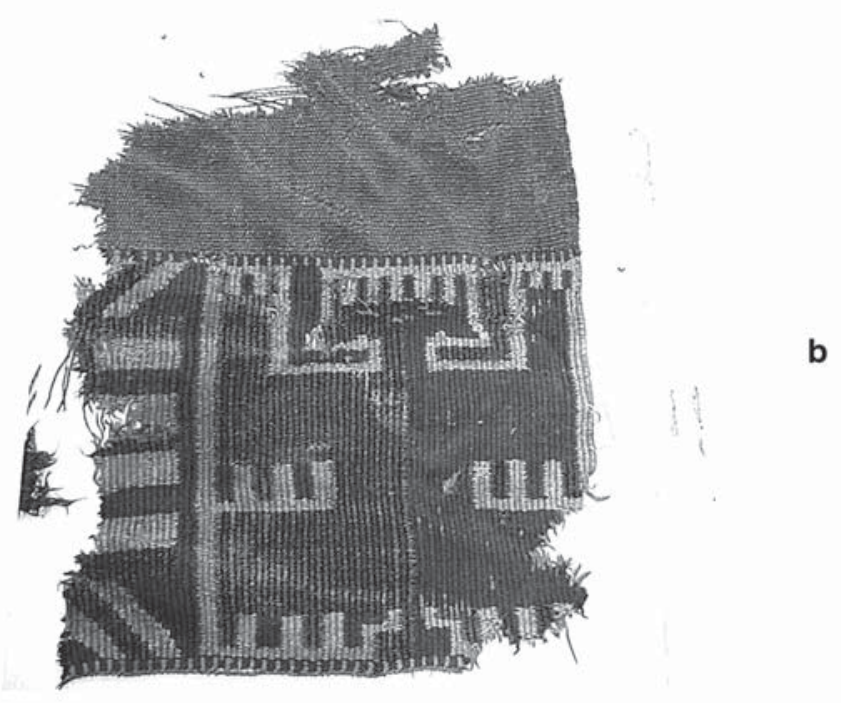

Figura 2. a) Banda inferior decorada y tejida en tapicería de túnica fragmentada de Az-70, $\mathrm{n}^{\circ}$ 130, sin contexto (MASMA). Foto gentileza de A. Peters; b) Fragmento lateral de banda inferior de túnica en tapicería (MASMA). Foto gentileza de J. Chacama.

tio Az-70, túmulo 1, pieza ${ }^{\circ} 124$, que contenía algunos elementos para insuflar narcóticos (Figura 3a). ${ }^{6}$ Esta pieza presenta el mismo patrón

6 Esta bolsa es absolutamente excepcional en el conjunto de los textiles formativos del norte de Chile. Efectivamente, en el registro textil de este período la presencia de bolsas tejidas a telar es aislada y se da en un número muy limitado; además se confeccionan en faz de urdimbre y no en faz de trama, y no presentan decoración alguna. Adicionalmente, aparte de esta bolsa, no se ha registrado ninguna otra con tan extraña forma: largo rectángulo con un extremo dobla- do sobre sí mismo para obtener una especie de "bolsillocontenedor". Por lo mismo, cabe plantear dudas acerca de la función original de ella, ya que podría corresponder a una banda inferior de túnica en tapicería, y constituir por lo tanto una reutilización textil más tardía, fenómeno que posteriormente -durante los períodos Medio e Intermedio Tardío- ha podido ser ampliamente observado en el registro textil (Agüero y Horta 1997 Ms). Recientemente, mientras este artículo estaba en preparación, Ann Peters tuvo oportunidad de examinar la bolsa en cuestión y confirmar la duda planteada más arriba, estableciendo un estrecho nexo con las bandas inferiores de túnicas de Az-70, y considerándola una reutilización de tal tipo de uncu. 


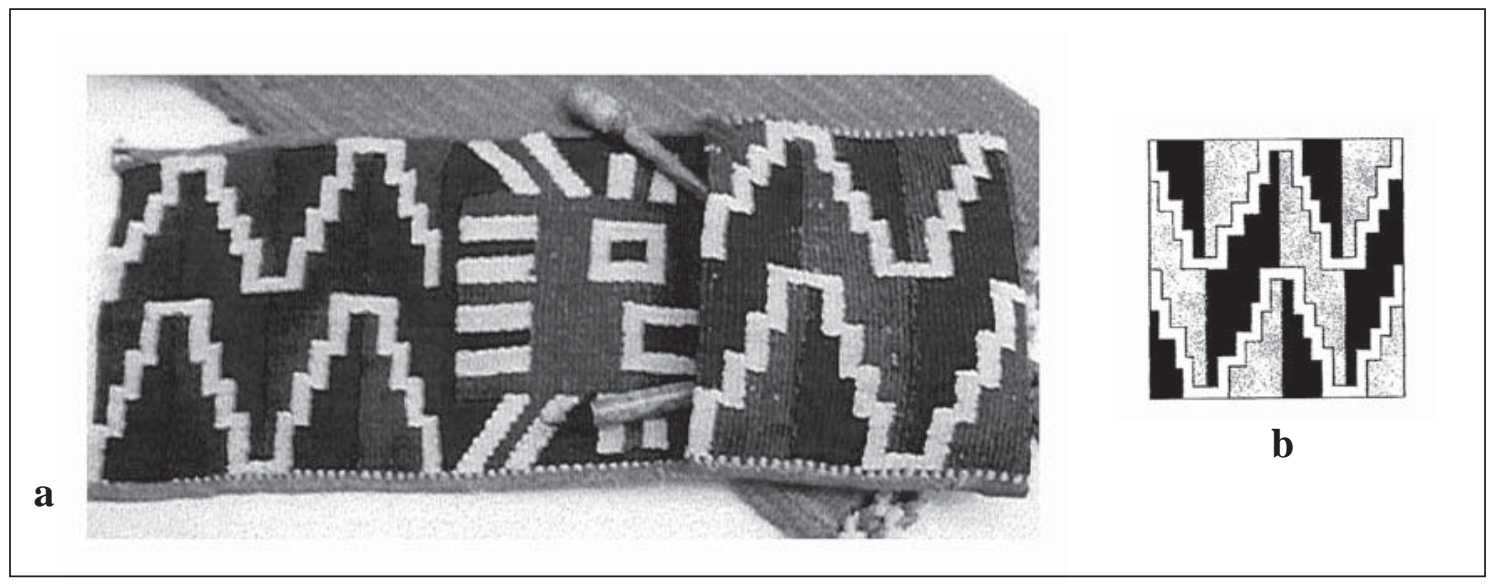

Figura 3. a) Foto de bolsa (?) en tapicería de Az-70, túmulo 1, $n^{\circ} 124$ (MASMA); b) Escalerado piramidal de cuatro peldaños. Motivo de la pieza anterior dibujado por P. Chávez.

composicional y los mismos colores de las bandas en faz de trama pertenecientes a las túnicas analizadas más arriba; la diferencia en este caso es que los iconos que flanquean la cabeza radiada son escalerados piramidales de cuatro peldaños, longitudinalmente divididos por contraste cromático en rojo y azul oscuro y enmarcados en crema (Figura 3b). Volveremos a analizar esta pieza más adelante, cuando abordemos el examen de las bolsas tubulares anilladas puesto que comparten iconografía entre sí.

\section{2) Taparrabos}

Según el registro realizado por Agüero y Cases (2004) los taparrabos tejidos a telar constituyen elementos conspicuos del ajuar personal. Frente a los más frecuentes faldellines de haces de totora o de hilados de fibra de camélido, los taparrabos son prendas excepcionales que presentan grandes dimensiones y técnicas diversas y, además, exhiben rica decoración. Obedecen a dos formas básicas: de reloj de arena o clepsidra, y rectángulo (Figura $4 \mathrm{a}$ y b); en ambos casos, el textil se dispone entre las piernas, dejando que los extremos (generalmente decorados por medio de bandas horizontales en faz de trama) pendan por el frente y la espalda del individuo portador, tal como es explicado por Sinclaire (1997). ${ }^{7}$

\footnotetext{
7 La autora mencionada entrega datos que avalan su definición de taparrabos para estas piezas textiles rectangulares de dimensiones aproximadas a $1 \mathrm{~m}$ x $50 \mathrm{~cm}$, que hasta aquí
}

El estudio de Sinclaire aborda el análisis de un conjunto de nueve taparrabos rectangulares con bandas horizontales en los extremos, decoradas en tapicería enlazada (dovetailed tapestry), e intenta vincular a dicho conjunto con manifestaciones del arte rupestre local. Todos provienen básicamente de la cuenca media del río Loa (siete de Topater-1, uno de El Salvador, uno de Chorrillos), y presentan idéntica técnica e iconografía común (Figura 4c). Agüero y Cases (2004) han reconocido, por su parte, un taparrabo idéntico entre el material de CaH-43, en la desembocadura del mismo río, así como un total de 16 taparrabos en Topater, basándose en el examen de fragmentos que por características de color, formato y técnica evidencian haber constituido prendas semejantes.

habían sido denominadas reiteradamente como "paños altares" sin aportar pruebas en favor de dicha supuesta función (Thomas et al. 1995). En el registro arqueológico de los pueblos agroalfareros del norte de Chile figura la inkuña o tari (textil cuadrangular de $45 \mathrm{~cm}$ x $50 \mathrm{~cm}$ de dimensiones promedio, y prolongaciones en las cuatro esquinas) con la función demostrada de contener hojas de coca. Comúnmente, son depositadas como ofrenda mortuoria, conformando un bulto pequeño (Horta 1999 Ms). Datos etnográficos indican que los pastores aymaras actuales utilizan textiles semejantes para ser usados como soportes de "mesas rituales" y depositar en ellos ofrendas en el curso de diversas ceremonias y ritos (marcaje de camélidos, por ejemplo; Zorn 1987). De ahí que a la inkuña arqueológica se le mencione en ocasiones como "paño ritual", pero tal denominación tampoco está avalada por la información arqueológica. Lo mismo ha ocurrido con los taparrabos en cuestión y su conceptualización como "paños altares". 


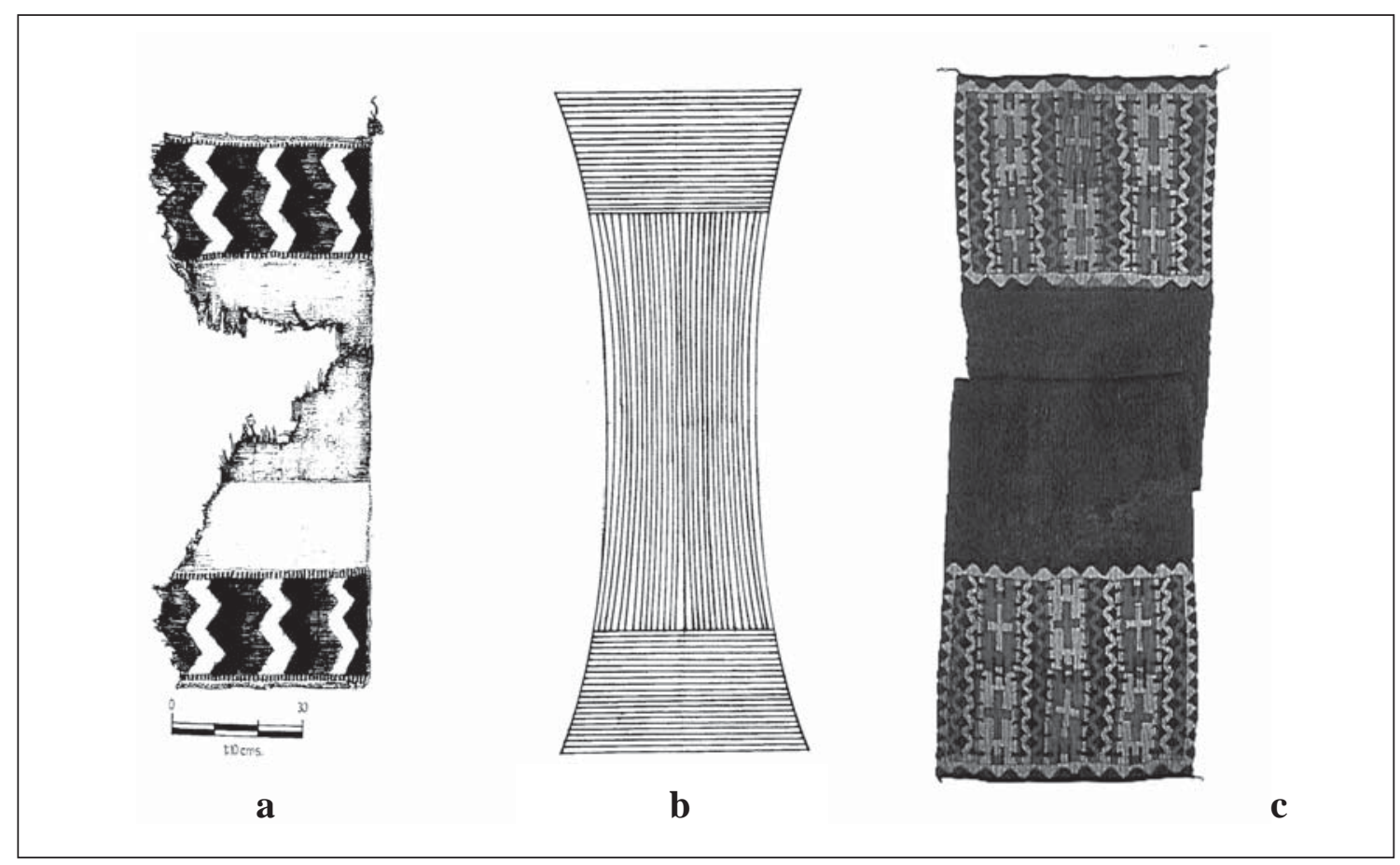

Figura 4. a) Taparrabo rectangular de Cam-15A, tumba 5 (disturbada), n 41 (MASMA). Tomado de Muñoz y colaboradores (1991); b) Taparrabo en forma de clepsidra proveniente de Pisagua-D, tumba 3. Tomado de Agüero (1999); c) Taparrabo de Topater-1 (Museo Municipal de Calama). Tomado de Gallardo y colaboradores (1999).

Llama la atención en relación con este tipo de taparrabo la fuerte estandarización de sus rasgos técnicos y de su iconografía. Según el registro de los taparrabos de Topater-1, los 16 ejemplares presentan una decoración compuesta de sólo dos opciones iconográficas. Una de dichas opciones es la "cruz inscrita en un rectángulo de contorno meándrico" (sensu Sinclaire 1997); este rectángulo va invariablemente acompañado en posición alternada por un "par opuesto de líneas en zigzag o quebradas", constituyendo una composición de paneles verticales rodeada en todo su perímetro por una línea zigzagueante denominada a su vez "motivo marco" (Figuras 4c y 5a, b y c).

La otra opción es un icono -sólo presente en el fragmento de Chorrillos (Latcham 1938: fig. 107) y en otro muy fragmentado de la colección de Topater-, compuesto por un antropomorfo frontal, de pie y con los brazos flectados hacia arriba, que posee una serie de atributos estables: cabeza radiada, boca y ojos rectangulares, apéndices colgantes desde los codos, símbolo compuesto inscrito en el abdomen, manos y pies bifurcados, pies divergentes, flexión o engrosamiento a la altura de las rodillas y apéndices como flecaduras a la altura de las caderas (Figuras 5d y 6a; en adelante este personaje será mencionado como Icono de Chorrillos para distinguirlo de otras imágenes análogas). Este icono, al igual de lo que ocurre con el rectángulo con cruz inscrita, es flanqueado por el "par opuesto de líneas en zigzag o quebradas", que fue mencionado más arriba.

Sinclaire reproduce en el artículo en cuestión otros dos fragmentos de taparrabos del sitio Topater-1 (cuadrícula D3), registrados por ella y que también presentan figuras antropomorfas (Figura 6b y c). Es interesante observar que la Figura $6 \mathrm{~b}$ presenta el mismo patrón composicional mencionado para el Icono de Chorrillos: boca y ojos rectangulares, apéndices colgantes desde los codos, símbolo compuesto en el abdomen, manos y pies bifurcados, pies divergentes, incluso conserva el arqueamiento de las piernas a nivel de las rodillas. El otro icono (Figura 6c) es bastante más abstracto, pero aún así conserva los brazos flectados hacia arriba, boca y ojos rectangulares y volutas "S" paralelas al tronco. 


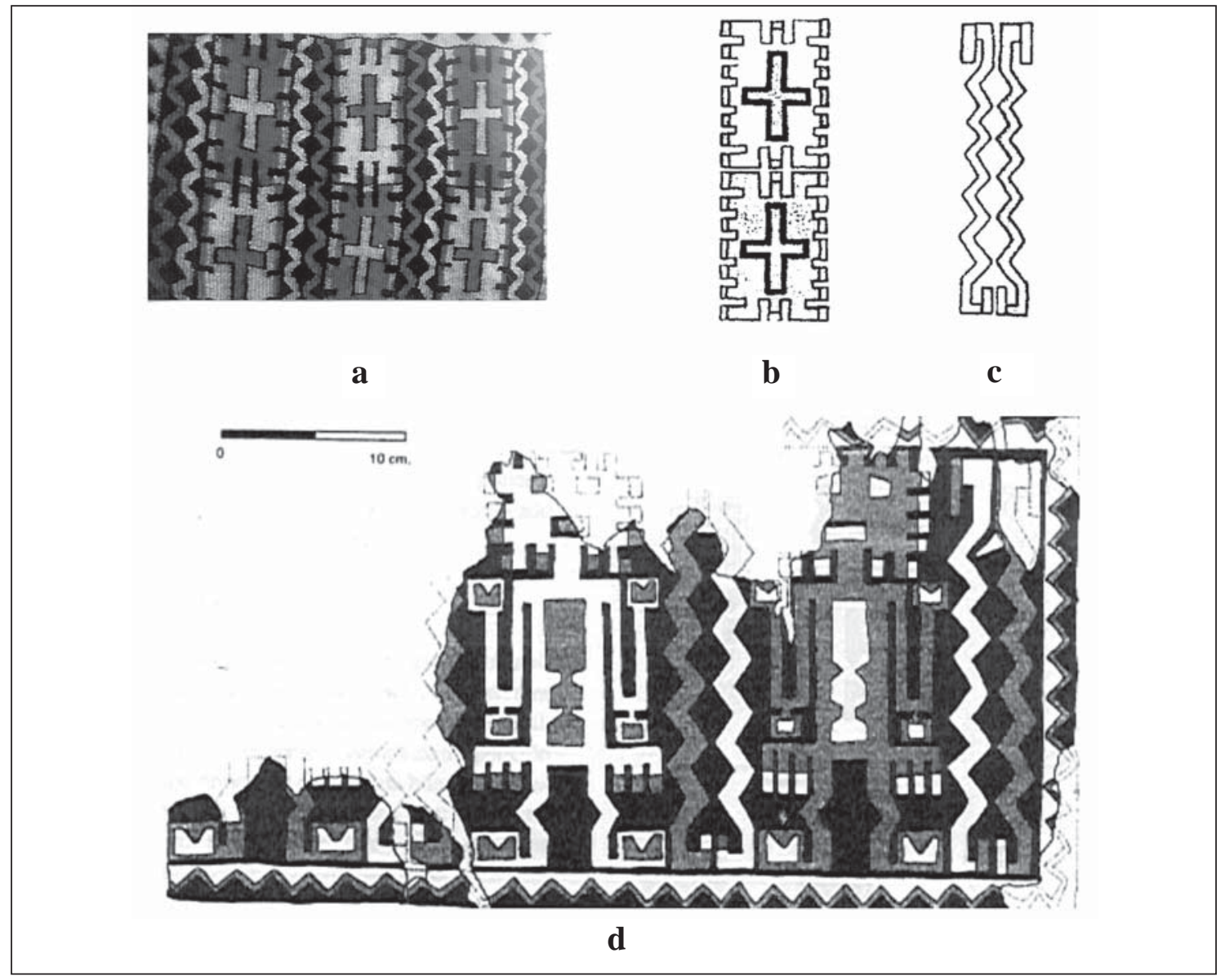

Figura 5. a) Foto detalle de taparrabo de Topater-1, sin contexto (Museo Municipal de Calama); b) Rectángulo meándrico con cruz inscrita (según Sinclaire 1997); c) Par opuesto de líneas quebradas (según Sinclaire 1997); d) Reconstrucción de taparrabo fragmentado proveniente de Chorrillos, n 10.950 (MNHN). Tomado de Sinclaire (1997).

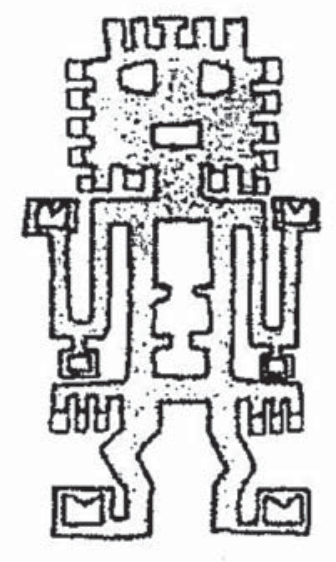

a

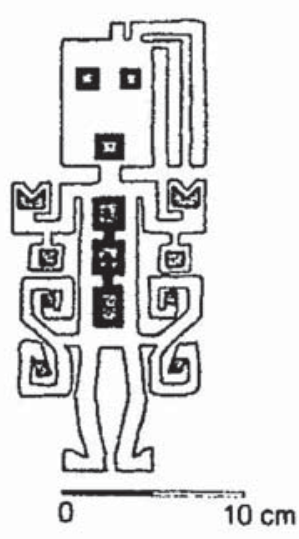

b y c

Figura 6. a) "Icono de Chorrillos". Tomado de Sinclaire (1997); b y c) Iconos de la decoración de taparrabos de Topater-1. Tomados de Sinclaire (1997). 
En el caso de la Figura 6b las divergencias con el Icono de Chorrillos son la ausencia del perímetro radiado de la cabeza y la transformación en voluta "S" de los apéndices-flecaduras a la altura de las caderas. No obstante ello, la conjunción de todos los demás atributos nos permiten plantear que en este taparrabo se alude igualmente al Icono de Chorrillos, y que, por tanto, la imagen de la Figura $6 \mathrm{~b}$ podría constituir una variación de él, a modo de diversas manifestaciones de un mismo universo semántico.

Hasta aquí, podemos observar que en el material textil de las dos áreas mencionadas (Azapa y Loa) empieza a esbozarse un específico círculo iconográfico, cuyo centro parece ser el Personaje Frontal de Cabeza Radiada. No hay muchas dudas respecto a que en el resto de los taparrabos de la cuenca del Loa el rectángulo con cruz inscrita ocupa exactamente el lugar del Icono de Chorrillos, en términos del sitio que es ocupado por este último al interior de la composición espacial de este tipo de prenda, tal como fuera advertido por Sinclaire (1997: 331). Más interesante aún es observar que, de algún modo no explícito, el rectángulo de contorno meándrico con cruz inscrita pareciera ser sinónimo sintáctico del Personaje Frontal de Cabeza Radiada (compárense las Figuras $4 \mathrm{c}$ y $5 d$ ).

Intentaremos aquí una interpretación alternativa para el "rectángulo de contorno meándrico", de acuerdo con el principio de la parte por el todo, pues parece plausible suponer que la cabeza del personaje podría estar reemplazando simbólicamente al personaje completo (Figura 7). Si observamos en detalle la forma de los apéndices cefálicos del Icono de Chorrillos, poniendo especial atención en el cambio de orientación que se advierte en los apéndices ubicados en dos de sus cuatro esquinas (las dos inferiores), es posible advertir una semejanza básica entre el contorno de los bordes meándricos del rectángulo y los contornos laterales de la cabeza del Icono de Chorrillos. Dicha semejanza también puede ser concebida como la compresión de los apéndices laterales hacia el eje central de la cabeza, o más bien, como si el segmento vertical central de ésta (segmento que une al cuello con la coronilla) se hubiese omitido en la representación; al mismo tiempo, si las dos esquinas inferiores -ya comprimidas como se ha propuesto- son reflectadas en si-

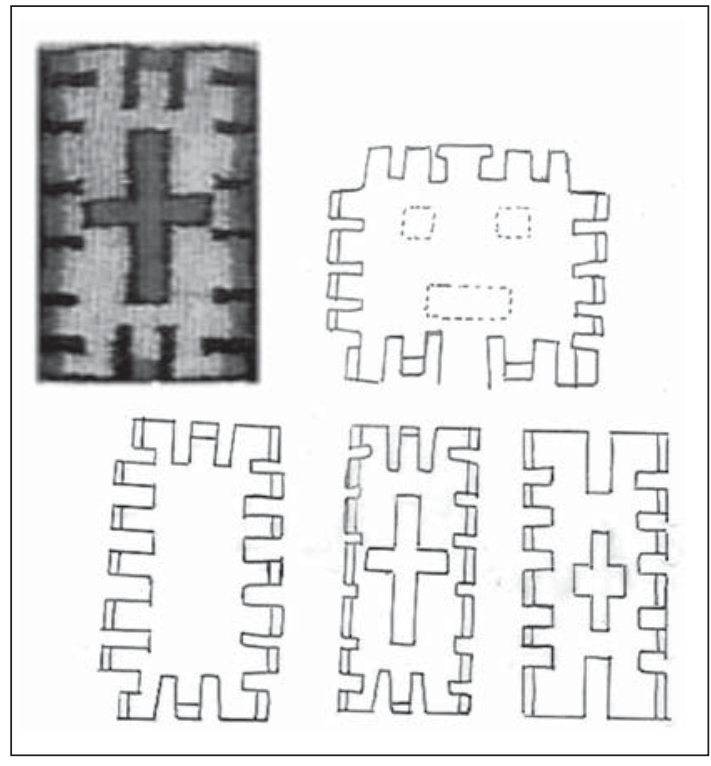

Figura 7. Hipotética transformación de la cabeza radiada en rectángulo de contorno meándrico.

metría especular horizontal, podríamos obtener un icono de nueva configuración, que basándose en el contorno meándrico de la cabeza del Icono de Chorrillos incorpora una cruz en su centro. Sea como sea, la posibilidad de interpretación de este hipotético proceso de "construcción" del rectángulo de contorno meándrico se encuentra en cierto modo avalada por la importancia que adquiere la cabeza radiada en la iconografía de este período: esta parte habría bastado para simbolizar al personaje completo. Más adelante veremos que en otra pieza la cruz de lados iguales también se ubica sobre la cara misma de una cabeza radiada (Figura $8 \mathrm{a}$ y b), lo cual refuerza el vínculo que intento establecer por el momento entre el rectángulo de contorno meándrico y el personaje frontal de cabeza radiada.

Aparte de las similitudes iconográficas, este conjunto de taparrabos presenta además sorprendentes normalizaciones a nivel de los colores empleados (rojo y azul oscuro, además de amarillo ocre), al igual que juegos muy estables de imágenes en positivo-negativo, e incluso las dimensiones parecieran obedecer a un patrón estandarizado (1$1.90 \mathrm{~m}$ x 50-60 cm; Agüero y Cases 2004; Sinclaire 1997).

Analizando la distribución geográfica de este tipo específico de taparrabos, hay que destacar el he- 


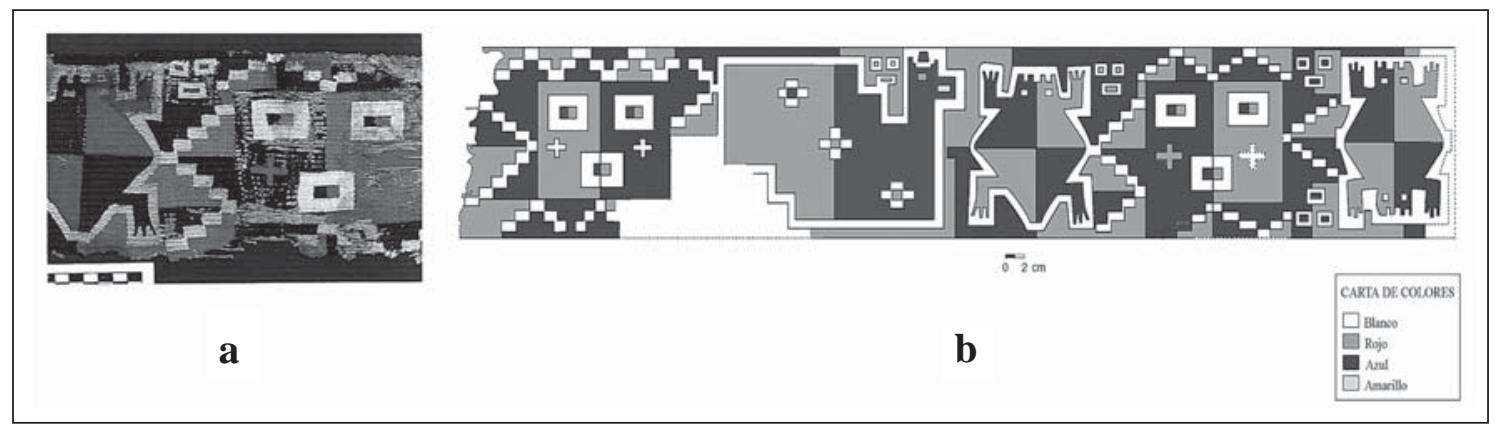

Figura 8. a) Foto de detalle de la tapicería sin función identificada de Az-115, sin contexto (MASMA); b) Dibujo desplegado de la tapicería anterior realizado por P. Chávez.

cho de su fuerte concentración en el área del río Loa, a través de su curso medio y desembocadura. En el extremo norte de Chile no ha sido encontrado hasta la fecha nada semejante. Con el taparrabo de Cam-15A (catalogado erróneamente como manta, puesto que el registro de Agüero y Cases lo consigna como taparrabo), y con otros dos de Pisagua-D y de Tarapacá-40, sólo hay similitudes técnicas y formales, pero no iconográficas (Figura 4a y b). No obstante, más adelante veremos cómo petroglifos, un geoglifo y una placa de oro de la misma zona contribuyen a esbozar una iconografía formativa propia común para Tarapacá y el Loa, con una única y notable aparición en la Puna de Atacama (quebrada de Tulan).

\section{3) Tapicerías sin función definida}

De un conjunto de cinco textiles confeccionados en distintos tipos de tapicerías, dos provienen de Tarapacá-40, uno de Topater y dos del valle de Azapa. En el caso de los dos ejemplares de Tarapacá-40, no se ha podido precisar con certeza a qué tipo de prendas pueden haber correspondido. A pesar de su número irrelevante en el conjunto textil global, son precisamente estos tejidos los que han incitado a distintos investigadores a plantear el origen alóctono del desarrollo Formativo en el norte de Chile, utilizándolos como pruebas de las influencias foráneas ejercidas en el área (Mujica 1985, 1991; Rivera 1976, 1984; Núñez y Dillehay 1978).

a) Ejemplar de Az-70 (tapicería enlazada o dovetailed). La más citada de todas es una pieza pequeña de $30 \mathrm{~cm}$ x $15 \mathrm{~cm}$, con cuerdas laterales anudadas en forma de $\mathrm{Y}$ griega, que evidencian su función de deformador craneano (Figura 9a y b) ${ }^{8}$ Debido a su decoración de cruces de lados iguales y cabezas humanas de perfil con indicación del pelo hasta la nuca, se la ha vinculado al desarrollo pre-Tiwanaku de Pukara, argumentando que en ella se patentiza el culto a las cabezas trofeo presente en la litoescultura y la cerámica de dicha cultura (Mujica 1985 y 1991).

b) Ejemplar de Tarapacá-40 (tapicería enlazada o dovetailed). Otra tapicería que ha servido para plantear influencias surperuanas (Paracas-Nasca) "vía culturas altiplánicas" (Núñez y Dillehay 1978) es un posible fragmento de manta con flecadura estructural, proveniente de Tarapacá-40 (tumba 87) (Figura 9c). En términos técnicos, esta pieza entrega evidencia de un rasgo muy poco frecuente en el ámbito de la textilería formativa local: tramas y urdimbres discontinuas en su sector lateral (Agüero y Cases 2004). También iconográficamente este fragmento es único: la serpiente (probablemente bicéfala, aunque el gran deterioro que ha sufrido no nos permite asegurarlo), de sinuosidad rectilínea, cuerpo radiado, decorada con cuadrados concéntricos y de hocico bífido, es un icono totalmente desconocido en el material textil del período que estamos analizando. ${ }^{9}$

8 En el registro textil de la zona conocemos piezas formalmente semejantes (formato pequeño, rectangular y cuerdas para amarre), que nos indican el uso de deformador craneano para ellas. Sirva mencionar el caso de un deformador craneano del sitio Az-6, tumba 109, $\mathrm{n}^{\circ}$ 12460, con dimensiones de $31 \mathrm{~cm}$ x $20 \mathrm{~cm}$, así como un deformador del sitio Pica-8, sector I, tumba 48, nº 1197; este último consiste en un textil doblado en sí mismo de $35 \mathrm{~cm}$ x $10 \mathrm{~cm}$, cuyos extremos presentan ojales y cordelillos para amarrarlo (Zlatar 1984: 163).

9 La serpiente, ya sea monocéfala o bicéfala, es un icono de escasísima recurrencia en este período. A excepción de los 


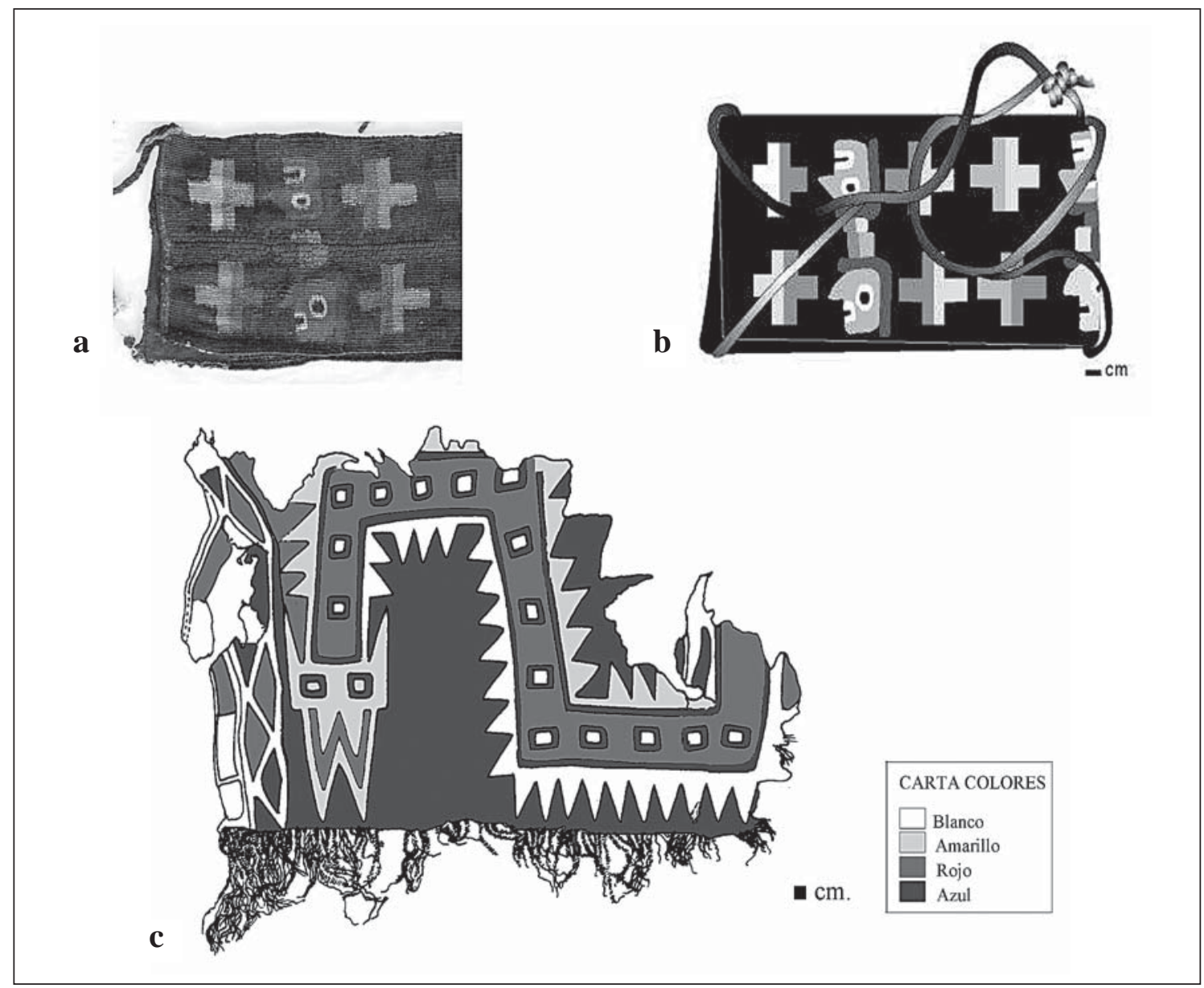

Figura 9. a) Detalle del deformador craneano de Az-70, sin contexto (MASMA). Foto gentileza de A. Peters; b) Dibujo de la pieza anterior tomado de Agüero y Cases (2000 Ms); c) Fragmento de manta en tapicería de Tarapacá-40, tumba 87. Instituto de Investigaciones Arqueológicas de la Universidad de Antofagasta. Tomado de Agüero (1999).

c) Ejemplar de Az-115 (tapicería entrelazada o interlocked). Este fragmento exhibe una iconografía sobresaliente. Sus curiosas dimensiones $(1 \mathrm{~m}$ de largo de urdimbre y $50 \mathrm{~cm}$ de ancho de trama) no han permitido clasificarlo en ningún tipo de prenda conocida para el período. En general, sus características técnicas, cromáticas (rojo y azul oscuros, más crema) e iconográficas la presentan

ejemplares monocéfalos en metal que se conocen para Az71 (Santoro 1981: figs. 1 y 2) y Playa Miller-7 (dos tupus del turbante $n^{\circ} 292$ de la tumba 54; Agüero 1994), además de la observación hecha por la autora de este artículo de un motivo de serpiente bicéfala en algunos cestos de Tarapacá40, no podemos considerar a la serpiente como un icono representativo, tal como sí es posible hacerlo en relación con el material textil del Intermedio Tardío (1000 DC-1470 DC) (Horta 1997, 2001b). como una pieza perteneciente al círculo de las túnicas con banda inferior en faz de trama del valle de Azapa (Figura 8a y b).

En dicho fragmento nos encontramos con la ya conocida cabeza radiada de boca y ojos rectangulares, pero en lugar de apéndices verticales presenta escalerados de tres y cuatro peldaños. Aparte de esta diferencia sutil y de la cruz de lados iguales que se aprecia en ambas mitades de su rostro, todos los demás rasgos (bicromía en rojo y azul oscuro, formato rectangular, ojos bipartidos) son concluyentes para permitirnos incluir a este fragmento en el círculo iconográfico del Personaje Frontal de Cabeza Radiada.

Los demás motivos que observamos en este textil son: (a) un ser zoomorfo de cuerpo romboidal 
cuatripartito, con cuatro extremidades flectadas en orientaciones opuestas y terminadas en tres dedos; presenta además una variante bicéfala y otra monocéfala. Su aspecto general corresponde a un sapo y la cabeza tiene ojos rectangulares y cuatro apéndices verticales paralelos; (b) cabezas pequeñas no radiadas, que aparecen ocupando espacios intermedios entre los iconos de mayor tamaño; (c) otro ser zoomorfo, sin extremidades ni cola, de hocico alargado y dos orejas rectas; su alto grado de deterioro no permite dilucidar en qué forma terminaba su cuerpo, pero es plausible suponer que pudiese haber rematado en otra cabeza idéntica, en orientación opuesta o, en su defecto, en cola. En todo caso, las características formales de este icono obedecen a los cánones de la representación de cuadrúpedos en general, y por lo mismo en este caso las alternativas se reducen a felino o a camélido. ${ }^{10}$

En relación con este textil es ineludible establecer otros dos paralelos iconográficos. Por un lado, tanto las cabezas radiadas de este fragmento como las que se pueden observar en las dos túnicas de Az-70 (Figura 2a y b) y en la pieza catalogada como bolsa (Figura $3 \mathrm{a}$ y b) presentan semejanzas notables con la imagen de una pictografía del Loa Superior (Figura 10a y b) (Horta y Berenguer 1995). Dichas semejanzas han sido comentadas en los últimos años por otros investigadores (Rivera 1995; Sinclaire 1997; Berenguer 2000). Es sorprendente el grado de correspondencia de la imagen que se puede observar en uno y otro soporte, así como el respeto por cada detalle de su configuración (bicromía o dualidad cromática; perfecto equilibrio entre apéndices cefálicos rectos y diagonales para las esquinas, entre otros).

d) Ejemplar de Topater (tapicería entrelazada o interlocked). Este tejido proviene de Topater, aunque se desconoce su contexto y pertenece actual-

\footnotetext{
10 Si la imagen en cuestión correspondiese a un camélido, y además presentase dos cabezas y un solo cuerpo, nos encontraríamos entonces frente a un icono conocido hasta la fecha sólo en el arte rupestre de estilo La Isla (300-1100 DC; Berenguer et al. 1985), en la región del Loa Superior. El camélido bicéfalo también ha sido observado en un cesto del cementerio Az-75, tumba 104, pieza n 1781 (Palma et al. 1995). No está de más señalar que la iconografía de dicho cesto es absolutamente excepcional en el conjunto de la cestería del norte de Chile.
}

mente a la colección del Museo Chileno de Arte Precolombino (en adelante MCHAP) ( $\mathrm{n}^{\circ}$ 2961). Tiene un formato cuadrado $(56 \mathrm{~cm} \times 53 \mathrm{~cm})$ con ojales o presillas en las orillas de trama; de una esquina cuelga un cordón, haciendo aún más enigmática la función de la pieza (Figura 11a). De todo punto de vista es una prenda atípica, al igual que su decoración y composición espacial. Sinclaire (1997: nota 15) entrega el dato adicional de que sus urdimbres son de fibra vegetal y la trama de camélido. Se puede apreciar que el centro del textil es ocupado por una cabeza rectangular aparentemente no radiada, en un tamaño muy pequeño en relación con las dimensiones totales de la prenda; al mismo tiempo, la boca, también rectangular, al igual que los ojos, exhibe dientes en forma de trazos verticales paralelos. En torno a este centro en forma de cabeza en miniatura surgen en dos de sus cuatro costados escalerados piramidales de cinco peldaños; cada uno de ellos es bicromo (rojo y azul oscuro) y remata a ambos lados en un amplio gancho o greca.

Esta pieza es especialmente interesante, porque reúne en una misma unidad iconográfica a una cabeza rectangular -a primera vista desprovista de apéndices cefálicos periféricos- y a escalerados piramidales; sin embargo, estos últimos podrían estar funcionando como apéndices, al igual de lo que ocurre con los escalerados que rodean la cabeza frontal del fragmento de Az-115 (Figura 9 a y b).

e) Ejemplar de Tarapacá-40 (tapicería ojalada o ranurada; slit tapestry; kilim o kelim). Es otra de las tapicerías cuya función permanece siendo un enigma (Figura $11 \mathrm{~b}$ y c). Su formato es muy parecido al ejemplar anteriormente analizado de Topater (Figura 11a). Fuera de esta pieza análoga, no ha sido detectada en el curso del registro arqueológico otra prenda similar para el Formativo del norte de Chile. Su decoración es igualmente peculiar, pero muestra alguna semejanza con el diseño de la bolsa anillada de Cam-15, que veremos más adelante (Figura 12d y e).

Como se desprende de la revisión de estas tapicerías, nos encontramos frente a un grupo minoritario, que a su vez presenta características estilísticas y técnicas bastante heterogéneas, pero que en términos iconográficos aportan a nuestro análisis. En forma especial hay que destacar al fragmento de Az-115, ya que del conjunto es el que sin lugar a 


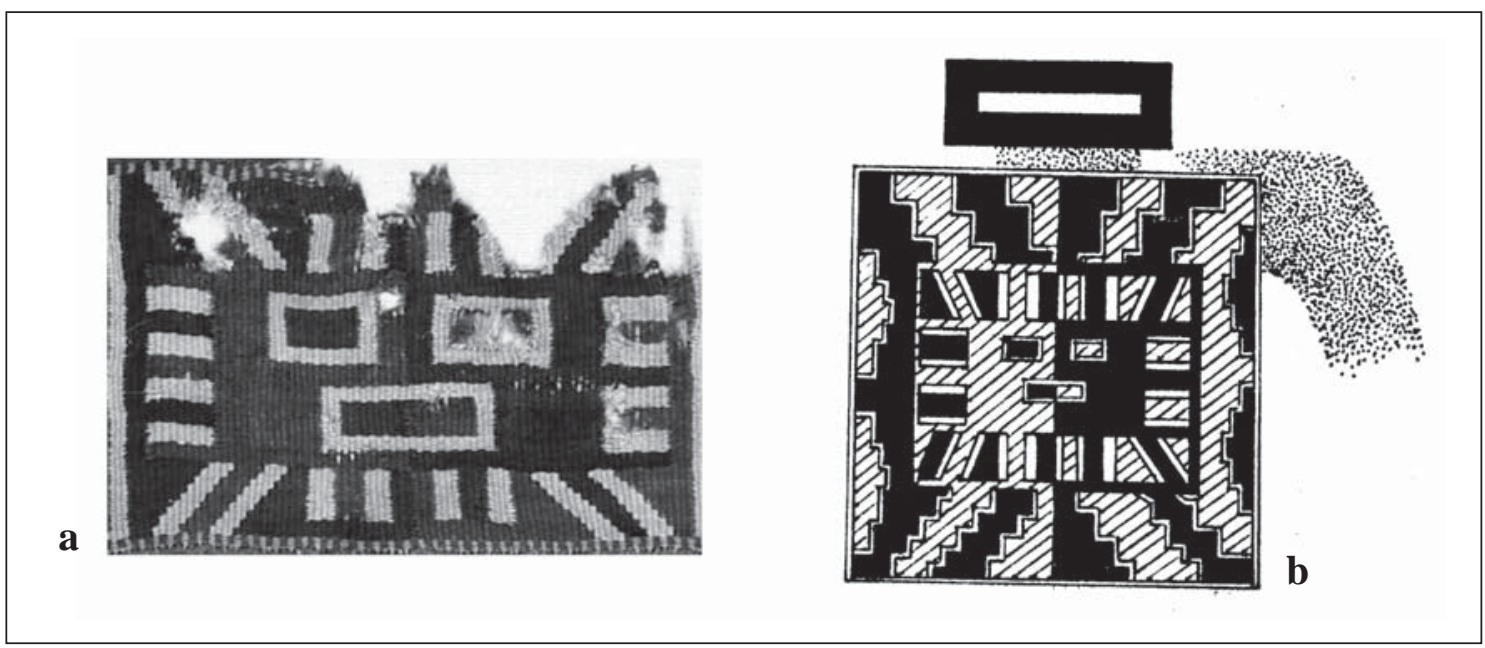

Figura 10. Representación de cabeza radiada: a) En textil: detalle de túnica $n^{\circ} 130$ de Az-70 (MASMA); b) En pictografía del Loa Superior, con escalerados. Dibujo de P. Chávez.

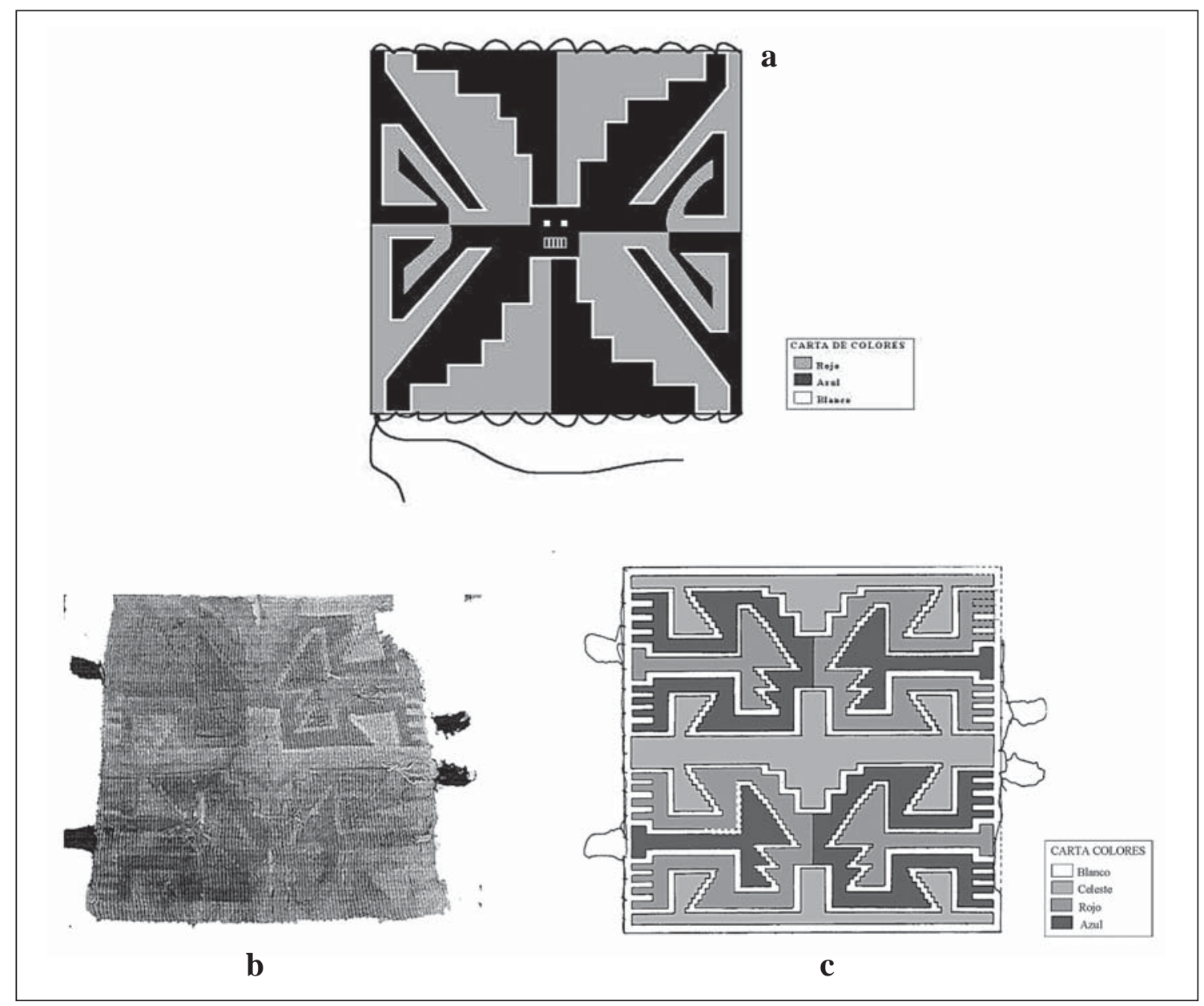

Figura 11. a) Textil nº 2961 de función no identificada, proveniente de Topater-3 (MCHAP). Dibujo de P. Chávez; b) Tapicería de función no identificada de Tarapacá-40, tumba 52 (Palacio Astoreca, Iquique); c) Diseños del textil anterior. Tomado de Agüero (1999). 
dudas pertenece al grupo iconográfico conformado por las dos túnicas y la bolsa de Az-70, tal como ya fue señalado. Por otra parte, los sitios de donde provienen las tapicerías analizadas son todos asignables al Formativo Tardío, a juzgar por las referencias contextuales (Agüero y Cases 2004).

\section{Tejidos en técnica de anillado (looping, simple-looping, netting)}

\section{1) Bolsas}

La confección de bolsas en técnica de enlace simple, malla o anillado es la manufactura -junto al tejido a telar de las mantas- más característica de este período (Agüero y Cases 2004). El anillado es por esencia tejido de un solo elemento, y contrariamente a lo que se podría esperar de una técnica aparentemente simple, es posible lograr con ella diferentes decoraciones complejas, al utilizar varias técnicas derivadas (anillado con doble torsión, anillado cruzado, anillado con doble torsión sobrepuesto y entrelazado, entre otros), y manejar simultáneamente diferentes densidades del tejido.

Esta gran variedad parece fundamentarse en la experiencia acumulada durante muchos siglos, puesto que la técnica del anillado ya está presente entre las tecnologías del Arcaico (bolsas anilladas en fibra de totora, algodón y camélido). ${ }^{11}$ Prueba de la continuidad cultural entre ambos períodos es, precisamente, que en el material cultural de los sitios formativos las bolsas anilladas en fibra vegetal ocupan un lugar tan destacado como el de las bolsas anilladas en fibra de camélido (Agüero 2002; Agüero y Cases 2004).

a) Bolsas tubulares. Al interior del grupo de las bolsas tubulares tejidas en fibra de camélido, es solo un subgrupo de un total de seis el que reúne el mayor número de piezas decoradas. En términos generales, su decoración es simple, limitándose a formas geométricas (bandas horizontales, pequeños rectángulos, franjas diagonales, etc.) y básicamente a los colores naturales de la fibra

11 Esta técnica es mencionada en relación con un fragmento decorado con escalerados y colores teñidos de la tumba 14 del sitio precerámico Tiliviche-2 (Standen y Núñez 1984: lámina 5f), al igual que con otras bolsas anilladas no decoradas, tanto de fibra vegetal como de camélido. animal (Figura 12a-e). ${ }^{12} \mathrm{~A}$ otro subgrupo de bolsas -cuyas bocas tienen un diámetro de $15-20 \mathrm{~cm}$ y no presentan decoración- debe pertenecer la publicada en fotografía por Rivera (1984: plate 3) y Soto-Heim (1987: fig. 4), conteniendo un cráneo humano (tumba 23 de Az-70; Focacci y Erices 1972/73). Esto merece tenerse en cuenta más adelante, durante la revisión del tema de las "cabezas trofeos".

De Cam-15 se conoce una pieza sin referencia a tumba, que exhibe una decoración más compleja de un escalerado piramidal de dos peldaños y líneas diagonales en ritmo alternadamente invertido, vale decir, podemos ver al escalerado indistintamente en posición normal e invertida, así como en su versión positiva y negativa; a través de la repetición de la inversión del icono básico se logra un diseño complejo, que como veremos a continuación no es un fenómeno iconográfico aislado en este tipo de bolsas tubulares (Figura $12 \mathrm{~d}$ y e).

Pertenece a la colección del MCHAP un grupo muy homogéneo -en cuanto a forma general y diseños- de seis bolsas tubulares sin contexto, que aparentemente provendrían del sur del Perú, probablemente de los alrededores de Arequipa. Lo notable es que la decoración de cada una de ellas presenta al escalerado piramidal como unidad básica, en el cual también se han introducido variantes de simetría en imagen-espejo y de inversión alternada (Figuras 13a, b y 14). La ubicación de la decoración al interior de la bolsa también guarda similitudes con el ejemplar anteriormente analizado de Cam-15: los diseños se sitúan a mi-

12 En relación con las bolsas tubulares decoradas con franjas horizontales café oscuro sobre un fondo café claro (Figura 19a), hay que destacar el hecho de que bolsas idénticas han sido registradas ampliamente en el material textil del Intermedio Tardío (1000 DC-1470 DC) del norte de Chile, con especial concentración en las ofrendas del cementerio costero Playa Miller-3, aunque también se ha dado cuenta de hallazgos similares en el valle de Azapa (Ulloa 1982), en la tumba 3 del cementerio Playa de los Gringos (Bird 1943 fig.13) y en Pica (Zlatar 1984). El caso de Playa Miller-3 es particularmente notable, ya que como cementerio prehispánico se halla vigente a partir del 1200 DC, perfilándose como el centro costero más importante del desarrollo cultural preincaico (Horta 2001a). Por lo mismo, ésta sería una demostración más del extraordinario conservadurismo que evidencian ciertas manufacturas desde el Arcaico hasta el Intermedio Tardío en el extremo norte de Chile. 


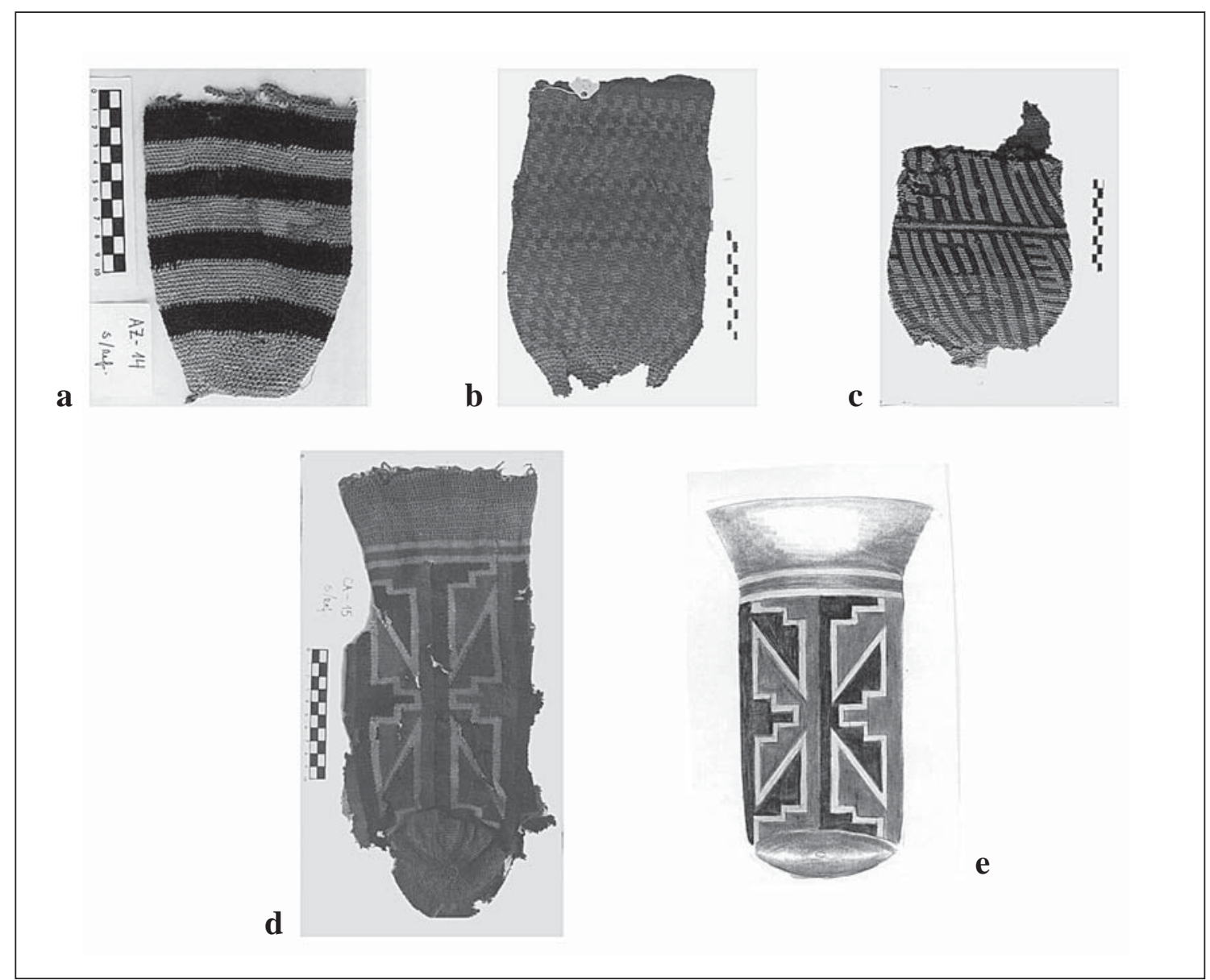

Figura 12. Bolsas anilladas tubulares de Az-14 (MASMA). a) sin contexto; b) tumba 0; c) sin contexto; d) Bolsa anillada tubular de Cam-15 (MASMA); e) Dibujo de J. Correa.

tad de cuerpo del campo textil, omitiendo decorar el último tercio del mismo; igualmente, el primer tercio cercano a la boca es separado del resto del cuerpo por medio de una línea horizontal demarcatoria. Este grupo difiere del ejemplar del extremo norte de Chile, en cuanto el sector cercano a la boca esta decorado con líneas verticales paralelas.

A nivel iconográfico podemos afirmar entonces que el icono central de estas bolsas corresponde a un escalerado piramidal de dos o tres peldaños, en general dividido longitudinalmente por el efecto de un contraste cromático entre café oscuro y café claro.

A esta altura del análisis, es menester volver al tema de la bolsa tejida a telar $\mathrm{n}^{\circ} 124$ de Az-70 que presenta una cabeza radiada (Figura 3a y b).
En esta pieza ya habíamos detectado al escalerado piramidal de cuatro peldaños dividido igualmente en forma longitudinal, lo cual nos permite unir en un todo iconográfico a las túnicas con banda inferior en faz de trama con dos diferentes conjuntos textiles: (a) con las bolsas tubulares (a través del escalerado piramidal), y (b) con los taparrabos en tapicería (a través de la cabeza radiada del icono de Chorrillos).

En términos iconográficos, es necesario destacar, entonces, que en el universo más amplio de las bolsas tubulares monocromas en técnica de anillado existe un grupo ciertamente menor de bolsas que presenta decoración geométrica simple, y esporádicamente representaciones zoomorfas de notable complejidad. Es el caso de la bolsa $\mathrm{n}^{\circ} 84$ de Topater-1 perteneciente a la colección del Museo de Calama (Figura 15). La decoración dispuesta 


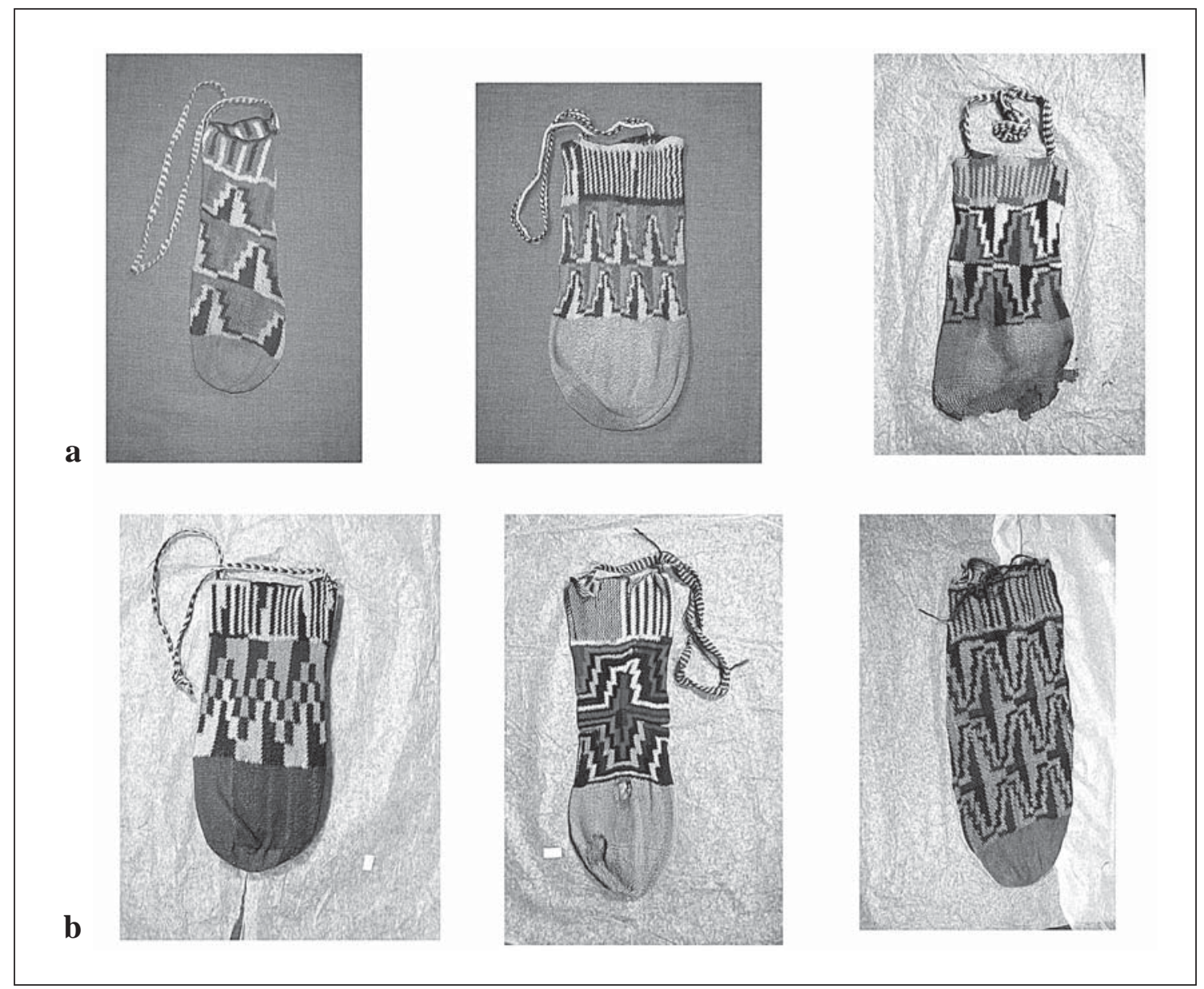

Figura 13. a) Bolsas anilladas ns 2764, 2809 y 2761 (MCHAP); b) Bolsas anilladas nº 2763, 2765 y 2762 (MCHAP).

en bandas longitudinales paralelas, en colores naturales de la lana de camélido, incluye una sucesión de "bustos" de una figura de difícil definición (¿batracio?) con extremidades flectadas que rematan en tres dedos, y una línea zigzag vertical con apéndices, que funciona como panel divisor. Es ciertamente notable que hacia la boca de la bolsa figuren, como un diseño aparte de la composición general de la pieza, escalerados de tres peldaños, divididos longitudinalmente en contraste cromático café oscuro/café claro, y que al mismo tiempo la "cabeza" del ser presente forma de escalerado. De esta forma, vemos que los elementos iconográficos presentes en las bolsas surperuanas también pueden ser detectados en ejemplares análogos del Norte Grande chileno.

b) Bolsas rectangulares. Las bolsas rectangulares, contrariamente a lo que ocurre con las tubulares, son escasas y referidas sólo a los cementerios del valle de Azapa (Az-70 y Az-71). La técnica empleada es anillado de doble torsión (Figura 16a). Aumenta su notabilidad el hecho de que ambos ejemplares conocidos son decorados con escalerados piramidales, y uno de ellos incluye hilados de colores teñidos (azul, naranja) junto a los naturales de la fibra (Figura 16b).

\section{2) Gorros}

En este período surgen por primera vez prendas tejidas para cubrir la cabeza. Anteriormente en el Arcaico no figura nada que posea una función semejante, a excepción de eventuales adornos cefálicos en forma de pelucas de pelo humano (Arriaza 1994), pero que en sí mismos no constituyen cubrecabezas. Ya en la Fase Azapa ( $c a .1300$ AC) del Formativo Temprano hacen su aparición 


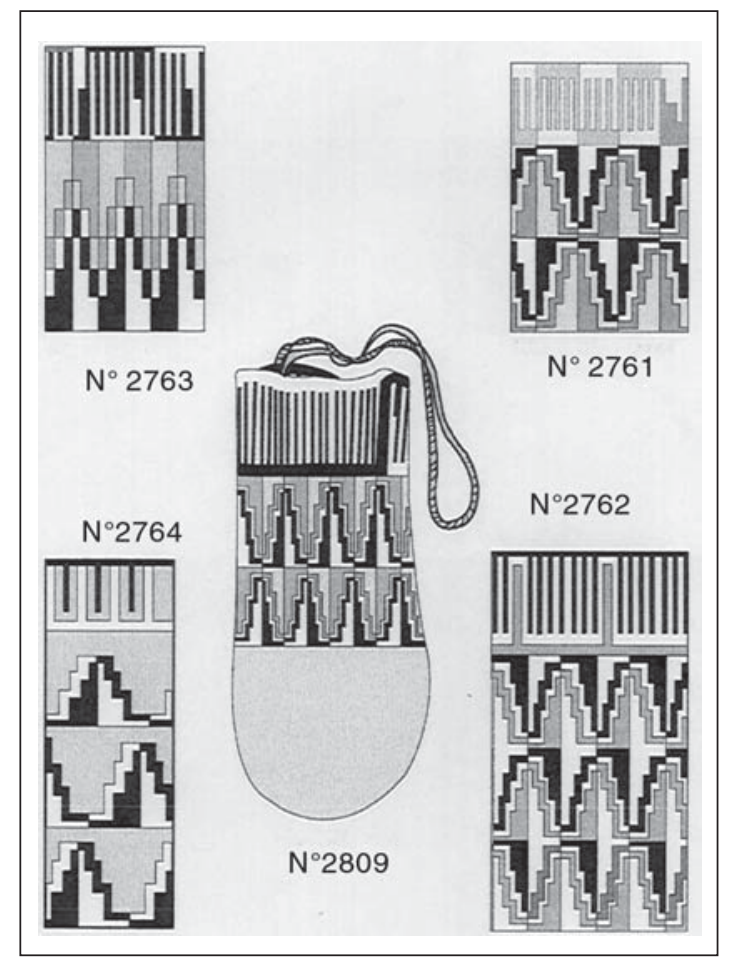

Figura 14. Diseños de las bolsas anilladas de la Figura 13. Dibujos de P. Chávez.

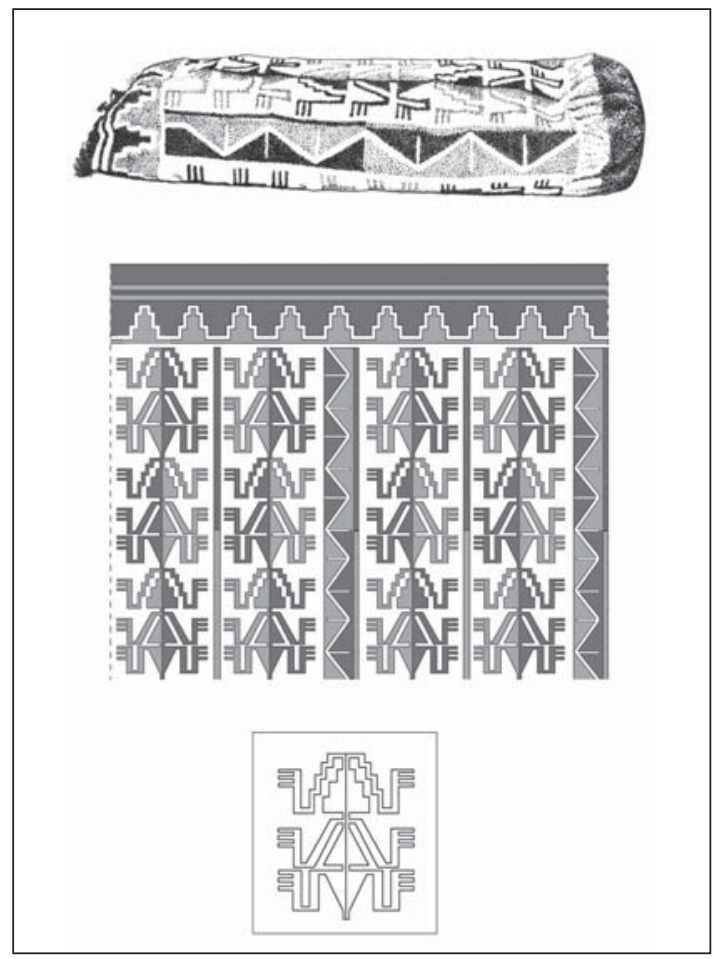

Figura 15. Bolsa anillada $\mathrm{n}^{\circ} 84$ de Topater-1 (Museo de Calama). Dibujo de P. Chávez.

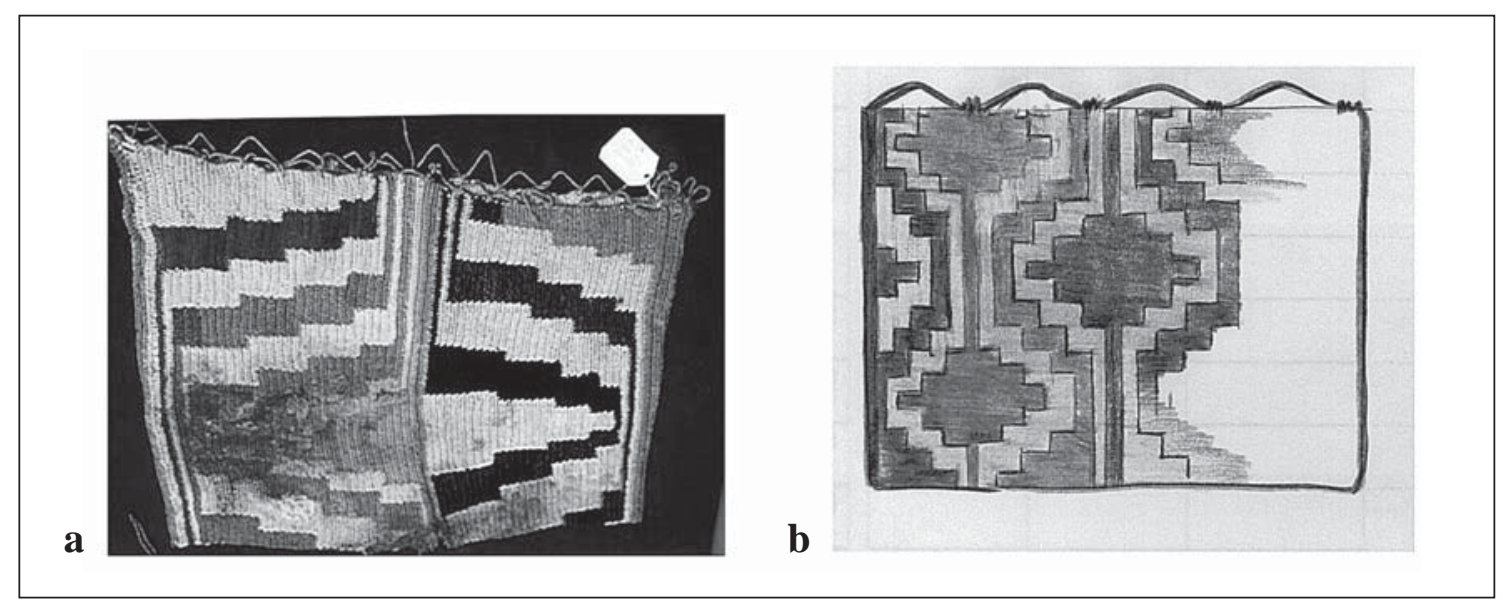

Figura 16. Bolsas anilladas rectangulares: a) $n^{\circ} 02012$ de Az-71, tumba 132 (MASMA); b) n 115 de Az-70, sin contexto (MASMA). Dibujo de J. Correa.

en contextos funerarios los característicos y ampulosos turbantes cefálicos de madejas de hilados de fibra de camélido, que coincidentemente con los colores de las tapicerías de Azapa son teñidos en café, rojo y azul oscuros y amarillo ocre (Agüero 1994; Santoro 1980). Lo que es necesario destacar en forma especial es la ocasional pre- sencia conjunta de gorros anillados y anudados con forma hemisférica dispuestos sobre o bajo los turbantes que adornan las cabezas (Agüero 1994 y 1995a; Núñez 1970; Moragas 1995; Gallardo 1993). De esta manera, todo parece indicar que los primeros gorros surgidos durante el Formativo Temprano son hemisféricos y no gozan aún de 
un papel totalmente independiente. Posteriormente, en el Formativo Tardío aparecen los gorros tubulares y desde ese entonces el gorro, tanto tubular como hemisférico, obtiene carta de ciudadanía, marcando de esta manera un hito más entre las múltiples innovaciones ocurridas durante este período.

a) Gorros tubulares. Los gorros tubulares confeccionados en anillado sencillo se hallan concentrados fundamentalmente en el valle de Azapa. ${ }^{13}$ Del cementerio CaH-43 se conoce otro sin mayores referencias, y recientemente fue descubierto uno en la colección de Topater y otro de Quillagua (Qui-84; Agüero et al. 1995; Agüero y Cases 2004). No deja de sorprender su total ausencia en los cementerios costeros de Arica, así como su escasísima representatividad en Topater.

Los rasgos característicos de este tipo de gorro son: su parte superior abombada, mientras que la inferior se denota levemente evertida, y el diseño estandarizado en forma de un escalerado piramidal de tres peldaños ubicado a medio cuerpo (Figura 17a). La mayoría de estos gorros aún conservan cuerdas trenzadas en los costados, que parecen haber servido para ser atadas bajo el mentón (en el caso del gorro de Az-122 las asas son de cabello humano; Muñoz 1987).

La decoración presenta una gama cromática estable (rojo y azul oscuros, crema, amarillo ocre), en una disposición particular de superposición de seis escalerados de distintos colores (Figura 17b). En realidad, nuevamente nos encontramos frente al recurso gráfico de utilizar alternadamente al escalerado piramidal en posición normal e invertida, sólo que en el caso de la decoración de este tipo de gorros uno y otro escalerado son separados por "sombras" escaleradas de diferentes colores. También hay que consignar el hecho de que el escalerado de los gorros no presenta la división

13 Az-70 ha aportado cuatro ejemplares (túmulo 1, pieza 127; túmulo 2, tumba 1, pieza 126; pieza 128 sin referencia; sin número y sin referencia). Del cementerio Az-122 se conoce un gorro de la tumba 12, que se hallaba in situ en la cabeza de un cuerpo masculino (Muñoz 1987). Completa el círculo de los gorros azapeños conocidos hasta la fecha un hallazgo de Az-14 sin referencia. La Colección Manuel Blanco Encalada (en adelante CMBE) también posee un gorro semejante proveniente de Az-70, sin referencias contextuales (C. Sinclaire, com. pers. 2001). cromática del escalerado de las bolsas anilladas (Figura 14) y la bolsa en tapicería (Figura 3a y b). Tampoco lo presenta la bolsa de la Figura 17c, que fue mencionada más arriba: este hecho reafirma la unidad iconográfica existente entre los diferentes tipos de prendas tejidas en anillado, y en especial el vínculo que queda así de manifiesto entre el grupo de las bolsas surperuanas y los gorros tubulares del norte de Chile.

De esta manera, podemos afirmar que la técnica del anillado, tanto en bolsas como gorros tubulares, hace uso de un mismo lenguaje iconográfico, centrado fundamentalmente en el escalerado piramidal.

b) Gorros hemisféricos. En el registro arqueológico los gorros hemisféricos son más frecuentes que los tubulares, y la mayoría de los casos no presentan más que los colores naturales del camélido (Agüero y Cases 2004). La técnica es igualmente anillada, pero en ocasiones muy densa, de forma que estos gorros tienen un aspecto rígido. Son escasos los ejemplares con colores teñidos: contamos con un número limitado de gorros decorados con simples franjas horizontales en colores naturales y teñidos (Figura 17d).

\section{Textiles formativos del norte de Chile y supuestas influencias foráneas}

El deformador craneano de Az-70 ha sido definido como "pieza utilizada para llevar las cabezas cortadas" y considerado "de estilo e iconografía Pukara” (Mujica 1991: 232). Junto con la definición estilística que se ha dado a esta pieza, la definición funcional es tanto o más discutible: hasta el momento no tenemos noticia de la existencia en el registro arqueológico de Valles Occidentales de piezas textiles confeccionadas expresamente para portar cabezas cortadas; por el contrario, contamos con tejidos a telar de pequeño formato con cuerdas en los extremos, y con dimensiones semejantes a las de la pieza en cuestión, que han sido definidos funcionalmente como deformadores craneanos, en un amplio rango temporal que va desde el Formativo hasta el Intermedio Tardío. ${ }^{14}$

\footnotetext{
14 Su recurrencia es baja en el registro textil de todas las épocas, siendo mucho más masivo el uso de cintas o fajas delgadas, que enrolladas en torno a la cabeza conseguían deformar el cráneo del infante (Agüero 1995b y 2000; Agüe-
} 


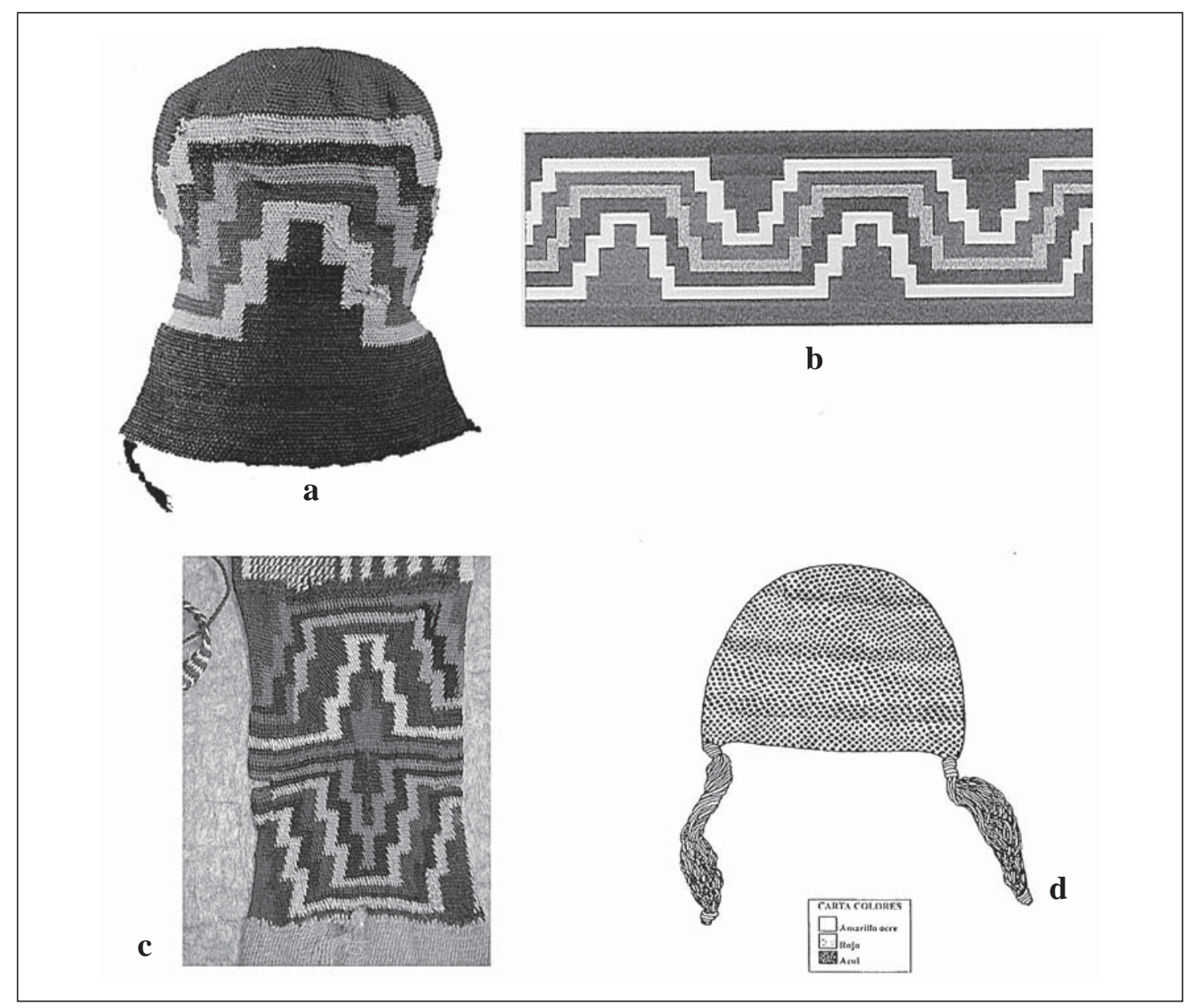

Figura 17. a) Gorro anillado tubular de Az-70 (MASMA). Tomado de Gallardo (1993); b) Dibujo desplegado de la decoración de los gorros escalerados, realizado por P. Chávez; c) Escalerado piramidal en dos soportes anillados distintos (ver Figura 13b; compárese con Figura 17a); d) Gorro hemisférico anillado de Topater-1, tumba J-5 (Museo Municipal de Calama). Tomado de Cases (1999).

La definición estilística de la pieza de Az-70 como de "estilo Pukara" ha sido resuelta tomando como base una supuesta semejanza entre los escalerados apreciables en la cerámica del sitio-tipo Pukara y los escalerados de las tapicerías analizadas más arriba, vale decir, extrapolando diseños cerámicos

ro y Cases 2004). Por otra parte, mientras este artículo estaba en preparación, Ann Peters examinó la pieza en cuestión y ha compartido conmigo sus observaciones técnicas, que por lo demás ha dejado consignadas en una ficha de registro llenada durante su visita al Museo Arqueológico San Miguel de Azapa (en adelante MASMA): "En suma, esta pieza tiene las evidencias de estar compuesta de dos fajas diseñadas como pares simétricos, pero que posiblemente tuvieron originalmente otro uso antes de ser unidas con una costura en el medio del textil". a textiles, y tomando como base un motivo geométrico simple: el escalerado, que en rigor no se halla presente en el deformador mismo.

Es preciso señalar que el "escalerado Pukara" mencionado como similar al escalerado piramidal de los textiles del norte de Chile (Gallardo 1993; Mujica 1991) no es homologable en términos formales: el primero es un triángulo de hipotenusa escalerada que debe ser comprendido como un conjunto, vale decir como la mitad de una unidad que integra a dos triángulos idénticos, pero en posición opuesta, y que de ninguna manera se asemeja al escalerado piramidal (Figura 18a) (Rowe y Brandel 1969: plate XII). Aparte de este hecho, un icono no debe ser observado aisladamente, como motivo en sí mismo; muy por el 


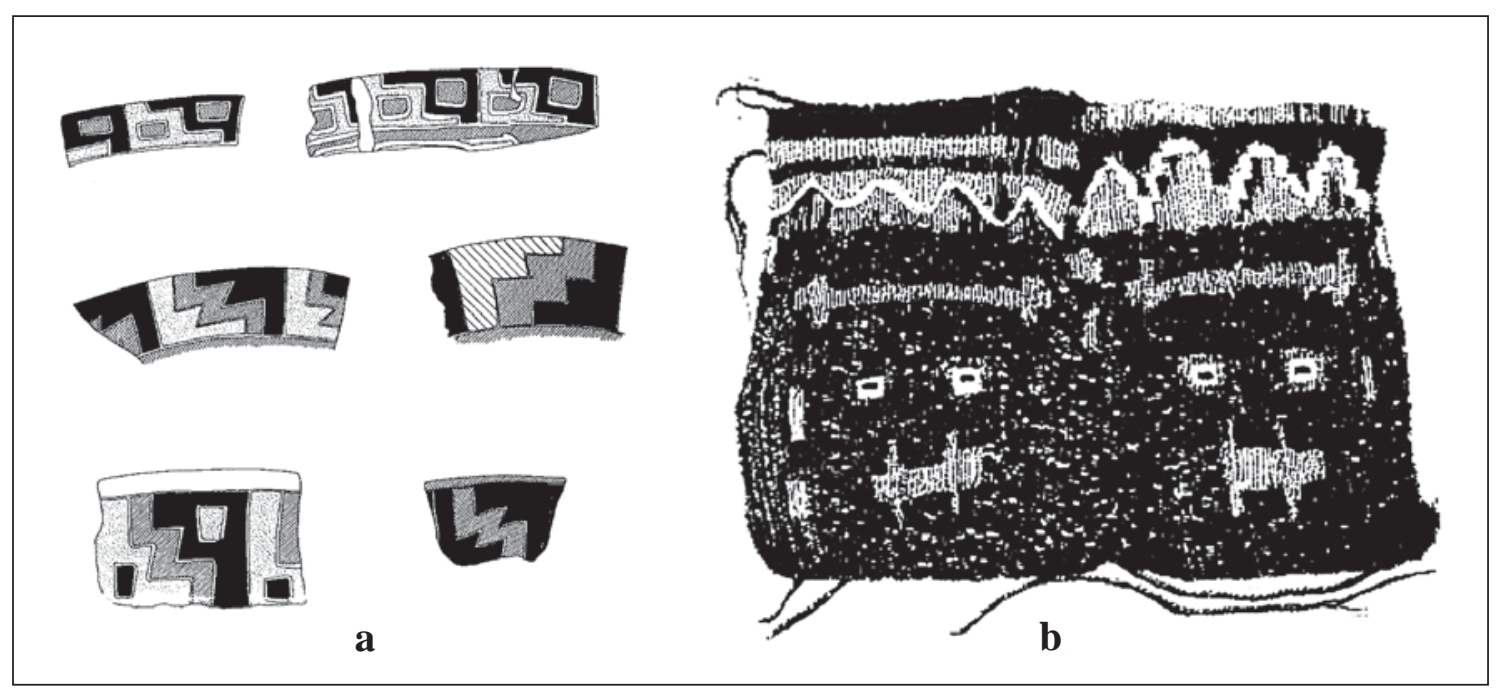

Figura 18. a) Motivo escalerado de la cerámica Pukara. Tomado de Rowe y Brandel (1969: plate XII); b) Bolsa en tapicería proveniente de Pircas-1. Tomado de Núñez (1984a).

contrario, es preciso examinar en qué configuraciones surge en relación con otros elementos. En el caso de la cerámica Pukara, el motivo escalerado aparece conjuntamente con otros iconos abstractos (rombos, círculos, cuadrados), conformando configuraciones más complejas que en ocasiones incluyen seres antropomorfos, aves, camélidos y felinos. En términos iconográficos, ninguno de estos últimos iconos presenta semejanza con los elementos del universo iconográfico del área que nos encontramos analizando.

Por tanto, el vínculo planteado entre el deformador cefálico de Az-70 y supuestas influencias Pukara es rebatible desde varios puntos de vista. Es primordial señalar que el rito o sacrificio de corte de cabeza humana (a través de un personaje Sacrificador) tiene una vigencia temporal muy amplia, y su distribución es incuestionablemente panandina, con diversas manifestaciones iconográficas regionales (Chavín; Paracas, Nasca; Noroeste Argentino: Condorhuasi, La Aguada; Altiplano: Pukara, Tiwanaku). Al mismo tiempo, las evidencias arqueológicas del norte de Chile que se tienen hasta el momento no permiten concluir en forma definitiva en favor de la existencia de tal práctica en las sociedades locales. De lo que sí hay evidencias es del desmembramiento de cuerpos post mortem, considerando en relación con ello múltiples variantes (agrupamiento de sólo extremidades, o de varias cabezas, intercambio de piezas óseas entre cuerpos dife- rentes, etc.). En el textil en cuestión podemos observar, además de las cabezas-trofeos de perfil, cruces de lados iguales (Figura 8a y b); éstas presentan la particularidad de la dualidad cromática que hemos señalado anteriormente en relación con las imágenes de bandas inferiores de túnicas (Figuras 2 y 3) y con la tapicería de Az115 (Figura 9a y b). Analizando los aspectos formales de las cabezas que decoran el deformador craneano, y sometiéndolos a comparación con las cabezas- trofeos de la cerámica Pukara, resaltan las siguientes diferencias: por una parte, las pupilas de las cabezas del textil no presentan la bipartición clásica de los ojos Pukara, que es característica incuestionable de dicho estilo en su manifestación cerámica; por otra, las cabezas del textil no tienen orejas, otro rasgo constante de las cabezas humanas Pukara.

En resumen, el supuesto "portador de cabeza-trofeo" de Az-70 puede provenir de cualquier punto del Altiplano sur-boliviano, de los alrededores del lago Titicaca o del sur del Perú, no existiendo nada que avale su procedencia exclusiva de Pukara. No debemos olvidar que se trata de una pieza textil única, sin peso en el conjunto de los textiles formativos del valle de Azapa, y de la cual desconocemos su contexto. En general, no parecen sostenibles los planteamientos que intentan establecer similitudes estilísticas y/o iconográficas tomando como base a piezas aisladas, las que, cuando son observadas en el contexto general de 
la iconografía propia de un área determinada, suelen resultar ser elementos intrusivos. La analogía aislada --por tanto, sin considerar los rasgos masivos de un universo iconográfico específico- es arma de doble filo, y puede inducir a establecer supuestas influencias entre áreas geográficas que en el pasado nunca estuvieron vinculadas culturalmente, o que sólo lo hicieron vía intermediarios.

A la luz de publicaciones recientes ha quedado en evidencia que el tema de la decapitación o corte de cabezas humanas es algo más complicado de lo que se pensó originalmente; en relación con las inhumaciones Chinchorro ya ha sido planteada la idea de trajines posteriores al entierro, al igual que con las prácticas mortuorias de otras comunidades post-Chinchorro, de las cuales se reportan casos de desmembramiento de cuerpos, y también de sustitución intencional entre miembros óseos provenientes de cuerpos distintos (Allison et al. 1984; Cartajena 1994; Focacci y Chacón 1989; Bittmann y Munizaga 1979; Santoro et al. 2001; Yacobaccio et al. 2001). ${ }^{15}$

Ya se trate de manifestaciones que obedezcan a un rito o patrón funerario o a decapitaciones que hubiesen provocado la muerte del individuo (sacrificio humano dentro de un rito específico), lo cierto es que la evidencia iconográfica textil local que pudiese apoyar la idea del sacrificio o del cercenamiento de la cabeza humana para conservarla como cabeza-trofeo es casi inexistente, reduciéndose a sólo dos textiles: por un lado, el deformador mencionado y una bolsa (?) en tapicería de Pircas-1 (quebrada de Tarapacá), con la representación de un rostro antropomorfo de ojos y boca rectangulares y escalerados piramidales decorando la abertura superior de la bolsa. La boca del rostro presenta la particularidad de hallarse atravesada por dos líneas verticales, al modo de como se suelen retratar las cabezas-trofeos en el arte Nasca (Figura 18b) (Núñez 1984a y 1984b; Muñoz 1989), y con el mismo aspecto que presentan las cabezas cortadas momificadas encon-

15 En el campamento semipermanente de cazadores de Chiu Chiu, en donde se excavaron dos estructuras, fueron encontrados restos óseos humanos mezclados con huesos de camélidos; más extraño aún es que dichos huesos humanos correspondían casi exclusivamente a extremidades, y más de la mitad hayan sido pies y manos (Cartajena 1994). tradas en el área de Nasca (DeLeonardis 2000). El carácter foráneo de esta pieza se ve reforzado por la presencia de otra bolsa en el mismo contexto (juntas formaban parte de un "escondrijo" al interior de un recinto), cuyas características de estructura textil y formato son completamente desconocidas en el material textil prehispánico chileno (Núñez 1984a: fig. 3). ${ }^{16}$ Por otra parte, se cuenta con tres fechados C14 para Pircas: 480 AC, 70 DC y 500 DC.

\section{En la búsqueda de iconos análogos (valle de Azapa, Pampa del Tamarugal, cuenca del río Loa y Puna de Atacama)}

Ya en 1985 Bente Bittmann, en parte siguiendo observaciones hechas por Reinhard en 1983, detectó importantes analogías iconográficas entre el textil de Chorrillos, el geoglifo del cerro Unitas (Figura 19a), un grabado ubicado en Ariquilda en la quebrada de Aroma (Figura 19b), otros dos grabados de Ariquilda y Tamentica (Figura 19c), y una lámina de oro de una tumba de Guatacondo (Figura 20a). El estudio de Bittmann se centraba en los geoglifos tarapaqueños, pero el análisis iconográfico la llevó finalmente a examinar el tema en la dimensión más amplia de las creencias andinas, planteando así que en tiempos prehispánicos el norte de Chile habría compartido con otras partes del mundo andino una iconografía religiosa similar difundida ampliamente; al mismo tiempo, plantea que los temas de dicho sistema ideológico ("Deidad Frontal", "Sacrificador", "ángeles" o "acompañantes", etc. y sus expresiones en la iconografía) eran comprendidos vastamente (Bittmann 1985: 11, 34).

Esta misma autora advirtió las semejanzas formales que se observan entre el Icono de Chorrillos y el geoglifo del cerro Unitas, pero en los años en que escribía su artículo poco o nada se sabía del material textil de Topater, y menos aún del lugar ocupado por dicho icono en el conjunto de los taparrabos locales. Comparaciones más precisas han sido posibles gracias al acopio de nueva información aportada por las investigaciones arqueológicas de los últimos años (Agüero 1995b y 2000;

\footnotetext{
16 Ninguna de las bolsas mencionadas ha sido hasta el momento analizada por expertos, pero en base a las fotos y a los comentarios realizados por Núñez (1984a) podemos estimar claramente el carácter foráneo observado en ellas.
} 


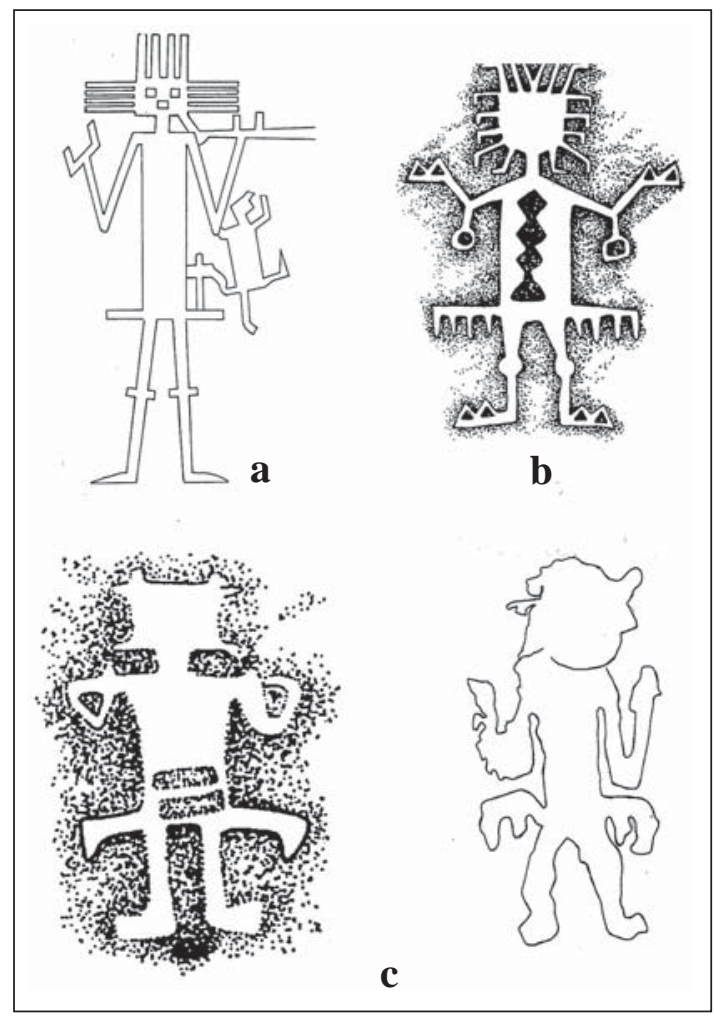

Figura 19. a) Geoglifo de cerro Unitas (I Región). Tomado de Bittmann (1985); b) Grabado de Ariquilda (Queb. de Aroma, I Región). Tomado de Chacama y Briones (1996); c) Grabados de Ariquilda-1 y Tamentica. Tomados de Chacama y Briones (1996) y Meighan (1980), respectivamente.

Agüero et al. 1995; Sinclaire 1997; Agüero y Cases 2004). ${ }^{17}$

Chacama y Briones (1996) intentaron por su parte homologar grabados de Ariquilda-1 con el tema Tiwanaku de la Divinidad Frontal con Báculos. También Santoro y Dauelsberg (1985) establecen relaciones estilísticas entre la cabeza radiada de las tapicerías de Azapa y el geoglifo del cerro

17 Tal como se verá en el texto más adelante, según el análisis realizado en este artículo, el icono representado por el geoglifo del cerro Unitas corresponde al primer tema iconográfico del Formativo Tardío, y en consecuencia podemos considerarlo como más temprano que el resto de los geoglifos del norte de Chile; éstos tradicionalmente han sido asociados al Intermedio Tardío, y tienen mayoritariamente una temática diferente que incluye camélidos en hilera asociados a figuras humanas y elementos geométricos. Por tanto, los resultados de la presente investigación corroboran a Bittmann (1985), quien ya lo proponía como más temprano.
Unitas. Sinclaire (1997) más recientemente publica el estudio ya mencionado, en el cual vincula la iconografía de los taparrabos de Topater con ciertos paneles del estilo rupestre Cueva Blanca del río Salado (Loa Superior).

Bittmann es, sin embargo, quien destaca las similitudes de atributos que ostentan imágenes en soportes tan diversos como son el metal, textil, roca y suelo. Entre tales atributos -a la luz de la información entregada por dicha autora- sobresalen como imprescindibles: la cabeza radiada, los brazos flectados hacia arriba, los pies divergentes y las flecaduras a la altura de las caderas. Bittmann no menciona en su examen de atributos los círculos pendientes desde los codos, que sin embargo pudo haber observado en relación con el textil de Chorrillos. Quizás la omisión se deba a que no los consideró "imprescindibles" iconográficamente, al igual que el engrosamiento de las rodillas u objetos sostenidos en las manos, los que pueden eventualmente faltar o ser omitidos en la imagen, sin que por ello el icono pierda nada sustantivo de su significación básica.

En relación con el atributo de los círculos pendientes desde los codos, cabe destacar que éste reviste especial importancia, puesto que es el elemento que nos permite unir iconográficamente con mayor certeza a este personaje formativo con el arquetípico personaje frontal Tiwanaku Clásico de la Puerta del Sol, quien exhibe pendiendo de cada codo un elemento circular con rasgos faciales humanos. Es muy probable que se trate de un mismo contenido, con variaciones formales.

Por otra parte, el sitio Tulan-54, en la Puna de Atacama, ha aportado información notable acerca de indicios de temprana complejidad social, con presencia de dos láminas de oro idénticas depositadas como parte del ajuar de párvulos ubicados bajo fogones datados entre 630-540 AC (Núñez 1992 y 1994). Más allá de la excepcionalidad del hallazgo, es de extraordinario interés notar que las láminas representan a un ser con una cabeza antropomorfa sorprendentemente parecida a la lámina de Guatacondo, referida más arriba (Figura 20a y b). La cabeza de las láminas de Tulan continúa hacia abajo en una franja zigzag, en lugar de presentar cuerpo, brazos flectados hacia arriba, pies divergentes, entre otros, tal como sucede con el Icono de Chorrillos. Sin embargo, es muy sugerente que tal ser de cabeza radiada re- 


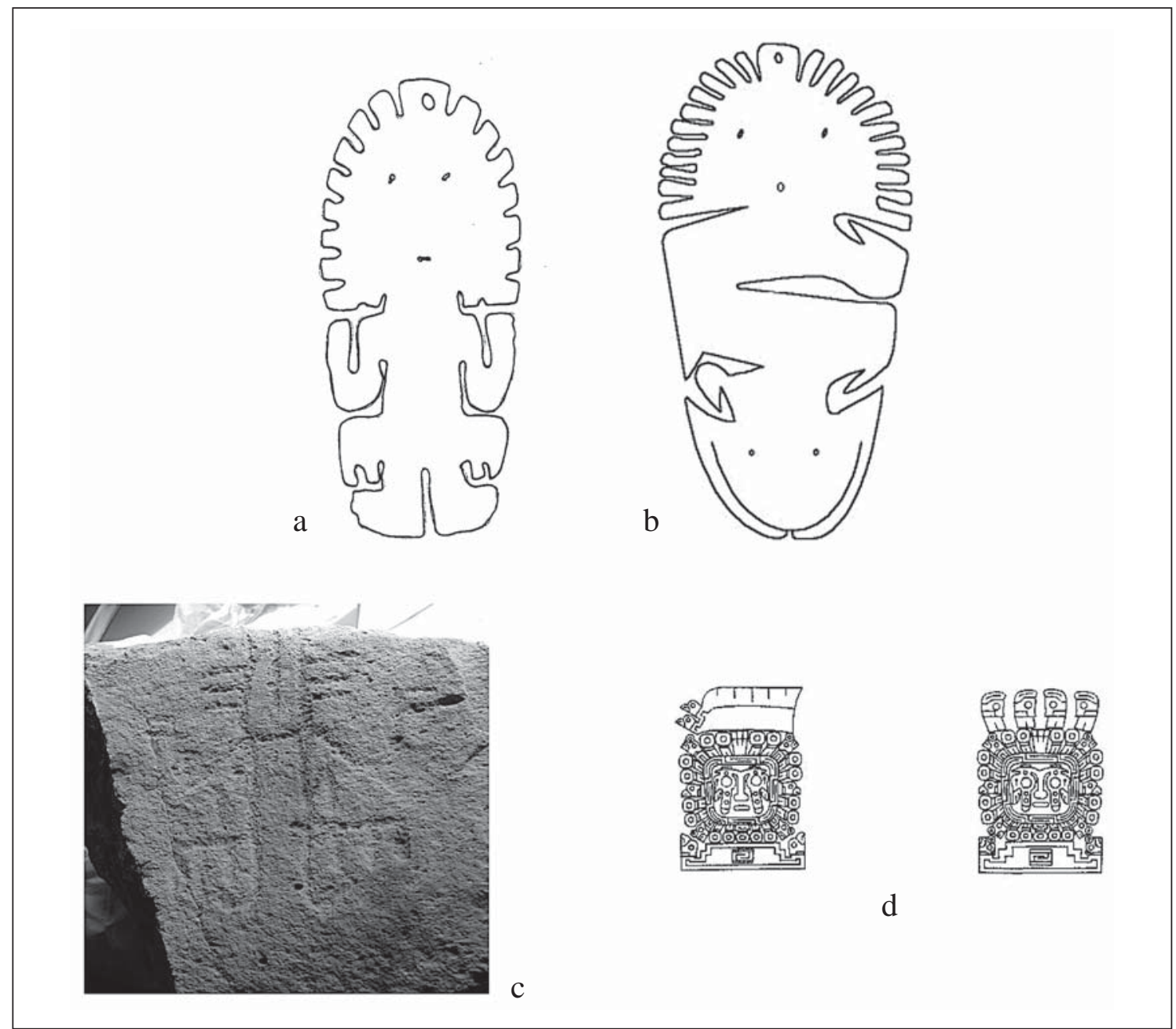

Figura 20. a) Lámina de oro de Guatacondo. Tomado de Meighan (1980); b) Lámina de oro de Tulan-54 (Museo Arqueológico R. P. Gustavo Le Paige s.j.). Dibujo de P. Chávez; c) Bloque grabado proveniente de cerro Chuño, valle de Azapa. Foto gentileza de O. Espoueys; d) Cabezas radiadas sobre plataformas escaleradas. Detalle del friso inferior de la Puerta del Sol de Tiwanaku (Posnansky 1945).

mate en una cabeza de otro ser, que no es antropomorfo, evidenciando quizás características de sierpe o de pez.

Al mismo tiempo, sorprende la similitud en la conformación de las cabezas radiadas de las tres láminas: ojos y boca en forma de pequeñas horadaciones, vástago ubicado simétricamente en el centro de la cabeza con otro orificio que permite su suspensión; además es importante destacar que cada una de las láminas presenta los apéndices radiados rodeando la cabeza en forma de abanico, pero al mismo tiempo podemos descubrir que se insinúa un engrosamiento para los apéndices de las esquinas, vale decir, se enfatizan las diferencias de orientación entre los ejes horizontales, verticales y diagonales (volveremos sobre este punto, porque parece reforzar la idea de que las imágenes de estas láminas anteceden en términos de configuración iconográfica a las cabezas radiadas de los textiles).

De la zona de Arica contamos con una imagen de arte rupestre de la ladera norte de la cantera Cerro Chuño, sitio cercano a los cementerios prehispánicos de Az-28 y Az-105. Se trata de un personaje grabado en un bloque aislado sin mayores referencias contextuales, y que actualmente se encuentra depositado en el Museo Nacional de Historia Natural de Santiago (en adelante MNHN), 
formando parte de la CMBE (Figura 20c). Los anchos surcos percutidos en la roca nos ofrecen la imagen de un personaje frontal, de brazos flectados en "V", cuya cabeza presenta apéndices radiados rectos y dispuestos simétricos y paralelos en torno a la cabeza, enfatizando la orientación vertical y la horizontal (tres por lado). También salta a la vista el uso de apéndices horizontales desde la altura de las caderas, especialmente el hecho de que casi tocan los pies evertidos. Toda la figura es resueltamente esquemática, minimalista, pero resaltan cada uno de los atributos señalados, denotando por lo mismo estrecha similitud con el Icono de Chorrillos, aunque en una versión simplificada.

\section{Temas iconográficos detectados para la fase tardía del Formativo}

La revisión arqueológica y bibliográfica, expuesta en las páginas precedentes, ofrece evidencias como para esbozar un primer tema iconográfico -con un Personaje Frontal de Cabeza Radiada como motivo central- que evidencia hasta el momento una dispersión geográfica acotada a las quebradas interiores de la Pampa del Tamarugal, al Loa y al valle de Azapa. Por el contrario, su versión más abstracta de Cabeza Radiada (acompañada en ocasiones por iconos zoomorfos) correspondería a un segundo tema iconográfico que parece tener presencia fundamentalmente en el valle de Azapa. Sin embargo, reforzando los vínculos con el material textil de la costa sur del Perú surge el estudio de Haeberli (2001) acerca de tejidos provenientes de valles vecinos a Arequipa, zona muy poco investigada hasta aquí (valle de Siguas y Vitor).

Este autor destaca la presencia de un icono que denomina Tema de la Cabeza Central Siguas, estableciendo tres variantes para el mismo. Su aspecto formal es el de una cabeza rectangular con apéndices rectos y diagonales, y opera como icono en sí mismo, aunque en ocasiones pueden acompañarlo motivos antropozoomorfos de importancia secundaria desde el punto de vista de la composición general de la pieza. En contraposición con el rostro del Icono de Chorrillos, éste cuenta además con nariz y adornos oculares, atributo presente más tarde en las representaciones del Personaje Frontal con Cetros de Pukara, Wari y Tiwanaku. Esto amerita énfasis especial, porque nuestro personaje formativo no presenta ni nariz ni adornos oculares entre sus atributos esta- bles. El icono arequipeño se destaca en más de 40 textiles de estilo Siguas 1 analizados por el autor, con fechados radiocarbónicos calibrados para sus tres variantes, que van desde el 200-36 $\mathrm{AC}$ a 55 AC-76 DC.

Por otra parte, también es notable el hecho de que entre fragmentos de piezas que parecen ser túnicas en faz de urdimbre, Haeberli señale listados laterales con diseño de "peinecillo" (Banda Listada Siguas 1 o BLS-1), que son en todo semejantes a los diseños detectados en un tipo de túnicas establecido por Agüero y Cases (2000 Ms y 2004). ${ }^{18}$ Igualmente interesante es destacar que según estas investigadoras este tipo se encuentra presente desde el Formativo Temprano en el norte chileno. Todo lo cual significa que no podemos ignorar las semejanzas iconográficas, ni las coincidencias técnicas y de formato de ciertos textiles del período en cuestión provenientes del norte de Chile y del sur del Perú.

Un tercer tema iconográfico estaría conformado por el Escalerado Piramidal en sus diversas variantes analizadas; su dispersión sobrepasa los límites actuales del norte de Chile, irradiándose por el extremo sur del Perú, en base a las bolsas provenientes de Arequipa. En este aspecto, pareciera que lo más típicamente formativo de esta iconografía es precisamente el Escalerado Piramidal; quizás futuras investigaciones aporten nuevos antecedentes para obtener un delineamiento más claro de sus verdaderos alcances geográficos.

\section{Atributos del Personaje Frontal de Cabeza Radiada}

En relación con el engrosamiento a la altura de las rodillas y las prolongaciones que arrancan desde las caderas presentes en la configuración del Icono de Chorrillos, podemos mencionarlos como los únicos atributos que no figuran entre

\footnotetext{
18 Este grupo corresponde a la siguiente definición: "túnicas cuadradas o rectangulares confeccionadas en faz de urdimbre, de largo igual o superior al ancho. Como decoración presenta a los lados, cubriendo un espacio de aproximadamente $6 \mathrm{~cm}$, listas de peinecillos dobles opuestos delimitados o alternados por listas finas. El color de las listas es café oscuro o rojo, y el fondo es siempre color vicuña, a veces con efecto de veteado" (Agüero y Cases $2000 \mathrm{Ms}$ ). En relación con este tipo, son ocho las túnicas reportadas: siete de Az-70 (MASMA) y una de Az-14 (CMBE).
} 
los elementos propios de la configuración del "Personaje Frontal con Cetros"; por su parte, los círculos pendientes desde los codos de nuestro icono persisten durante largo tiempo en imágenes de diferentes soportes y asociaciones cronológicas (Pukara y más tarde Wari y Tiwanaku).

El engrosamiento de las rodillas puede estar relacionado con el uso de rodilleras y tobilleras, elementos de la vestimenta de este período; ambos se encuentran refrendados en el material arqueológico del norte de Chile. Respecto a las prolongaciones desde las caderas la cosa no es tan clara, surgiendo varias alternativas. Una de ellas sería la graficación del faldellín en uso en esta época, pero cabe también preguntarse si no podría ser la representación de algún elemento ajeno a la vestimenta.

Por tanto, nuestro icono sólo se conforma de un personaje frontal de cabeza radiada y brazos flectados hacia arriba, sin báculos o cetros, pero los círculos pendientes de los codos ya forman parte de sus atributos; también surge opcionalmente en su versión abreviada (sólo como Cabeza Radiada) y se vincularía a un Escalerado Piramidal. En todo caso, su vínculo parecería no ser estable, ni conformar con él una unidad, tal como ocurre en el caso del icono altiplánico y su relación con la plataforma piramidal.

El cambio simbólico más importante que se habría producido entre el Personaje Frontal de Cabeza Radiada del Formativo de Valles Occidentales y el "Personaje Frontal con Cetros" de tierras altas, sería precisamente que este último fue investido de un poder específico explicitado por medio de los cetros o báculos. Con muy pocas excepciones, éstos no serán omitidos de sus representaciones mientras dure la influencia Tiwanaku en el área surandina (Cook 1994)

\section{El Personaje Frontal de Cabeza Radiada, el pez-sierpe y el batracio}

Valga hacer notar en relación con las láminas de oro de Guatacondo y Tulan-54, que debido a sus características formales, técnicas e iconográficas, éstas indudablemente deben ser consideradas como parte del mismo círculo de manifestaciones visuales formativas (Figura 20a y b). Al mismo tiempo, estas láminas nos permiten vincular a sitios distantes como son las quebradas de Tarapacá (Guatacondo) con la Puna de Atacama (Tulan).
Las láminas de Tulan -asociadas como ya hemos visto a fechados que nos las ubican probablemente entre el 630-540 AC- nos entregan información adicional acerca de las distintas formas de aparición del Icono de Chorrillos: en este caso, es precisamente sólo su cabeza la que recibe énfasis (radiada y frontal), pero su cuerpo se funde con el cuerpo de un posible pez. Esto es especialmente interesante, porque desde el punto de vista iconográfico nos enfrentamos a una singular equivalencia entre el icono frontal completo (Figura 20a) y su versión abreviada de cabeza radiada y fusionado a otro ser (Figura 20b); al mismo tiempo, la ubicación cronológica del sitio arqueológico Guatacondo (G-1) establece una vigencia posterior para la lámina proveniente del mismo: alrededor de los inicios de nuestra era (Meighan 1980). Por lo mismo, es plausible plantear que en Tulan-54 el icono formativo todavía no contaba con la configuración definitiva que le hemos conocido para tiempos posteriores, en su forma de Icono de Chorrillos.

Por otra parte, y en relación con las mismas láminas, es necesario destacar otra situación especialmente importante. Tal como se desprende del artículo de Chávez y Mohr (1975) sobre la litoescultura temprana o pre-Tiwanaku de la cuenca del lago Titicaca, así como del trabajo de BouysseCassagne (1988) acerca de las representaciones de mitos de la misma zona, la iconografía de la época se circunscribe a un número limitado de motivos antropomorfos, zoomorfos y geométricos. Entre las imágenes de monolitos de Pukara, Arapa, Hatuncolla y Tiwanaku sobresalen un batracio y un pez; este último es representado con cara frontal, y antenas o bigotes saliendo de ella, y parece corresponder al suche o mauri (Trichomycterus rivulatus; Trichomycterus dispar), peces nativos del lago.

Las representaciones del suche tienen cuerpo serpenteante y rostro con ojos, boca, nariz y orejas (Chávez 1975: plate V; Mujica 1991: figs. 222223; Portugal 1957: fig. 138). ${ }^{19}$ No hay que ir muy lejos en la búsqueda de analogías para dicho pez,

19 Conviene aclarar que en las representaciones Tiwanaku también figura el pez boga (de la especie Orestias), pero que éste es representado de perfil, sin antenas y con labios protuberantes. Por lo tanto, su forma de representación es fácilmente distinguible de la del suche (Posnansky 1945: plate XXVI). 
puesto que lo encontramos en la Puerta del Sol de Tiwanaku, en el entorno directo del "Personaje Frontal con Cetros": tanto en el centro de la plataforma escalerada sobre la cual la deidad se encuentra erguida, como en el centro de su pecho y en el medio de los apéndices radiados que rodean su cabeza. Tal como ya vimos, la lámina de Tulan-54 remata en un ser de cuerpo serpentiforme, y su rostro presenta orejas, dos ojos pequeños y una gran boca delineada (Figura 20b). Las semejanzas permiten a mi juicio plantear la posibilidad de que nos encontremos frente al mismo pez-sierpe de los monolitos circumtiticaca de tiempos pre-Tiwanaku, el cual pareciera sobrevivir por lo menos hasta la etapa clásica de Tiwanaku (Posnansky 1945).

Por su parte, las representaciones del batracio son especialmente frecuentes en asociación a monolitos Pukara (Monolito de Hatuncolla, colección del MNAAH del Perú; Monolito "Rayo", Posnansky 1945: figuras 152-152a) y en dos casos fueron grabados en la espalda o los hombros de estatuillas con forma humana (Mujica 1991: fotos 186 y 187; Chávez 1975: plate VII). Aunque desconocemos la función de tales monolitos y estatuillas, lo más plausible es suponerles un uso ritual, como objeto de algún tipo de ofrenda o rogativa.

Tanto en el caso del pez-sierpe o del batracio, hay indicios que nos permiten suponer que en ambos se alude al agua, muy probablemente al agua de lluvia (Gisbert 1980). Tal como ya vimos, un ser con aspecto de batracio acompaña en tres oportunidades (o cuatro si consideramos en el cálculo el fragmento de Camarones reportado por Chacama) al icono Cabeza Radiada en textiles del extremo norte de Chile, de tal modo, que la asociación al agua planteada también podría ser válida para el vínculo del pez-sierpe y el batracio con el Personaje Frontal Radiado. Cuando observamos que tanto en el caso del icono formativo de Valles Occidentales como en el de manifestaciones líticas altiplánicas ambos seres figuran como elementos asociados, es inevitable pensar que el carácter de la deidad debe haber estado relacionado con el control de la lluvia (Reinhard 1991).

\section{La Cabeza Radiada}

Por su parte, la Cabeza Radiada, en su condición de icono en sí mismo, se concentra fundamental- mente en las tapicerías del valle de Azapa, con sólo dos apariciones más al sur: en la pictografía del Loa y al interior del valle de Camarones. Respecto a su forma general, conviene destacar un rasgo importante de su configuración; se trata del cambio de dirección que se puede apreciar en la disposición de los apéndices que rodean el rostro: vertical para los apéndices superiores e inferiores, horizontales para los laterales y diagonal para los de las esquinas (sobre este fenómeno ya habíamos hecho mención en relación con los apéndices en forma de abanico de las láminas de Guatacondo y Tulan). Este canon de disposición general de los apéndices se observa en las configuraciones posteriores de Tiwanaku Clásico y Wari, y además enfatizado por medio de la utilización de diferentes remates de apéndices en forma de anillos o círculos concéntricos, cabezas de felinos, aves y peces, y elementos vegetales como maíz y otros (Chávez 1984/85; Rowe 1976; Knobloch 2000).

Por otra parte, los elementos constantes de la configuración del rostro no incluyen nariz: este es otro rasgo importante que marca la diferencia respecto a las cabezas radiadas de Pukara, Wari y Tiwanaku. Lo mismo vale mencionar en relación con la ausencia de adornos oculares, orejas, colmillos entrecruzados y marco periférico del rostro con forma de greca, atributos estables de las deidades altoandinas.

Hay que destacar en relación con la Cabeza Radiada que la litoescultura de Tiwanaku, conjuntamente con el "Personaje Frontal con Cetros", también nos presenta la figuración de su cabeza aislada, vale decir, la versión abreviada de la misma (parte por el todo), y además esto ocurre de acuerdo a una configuración estable que incluye cabeza radiada y escalerado piramidal (Figura 20d). Esto ocurre paralelamente en los frisos inferiores respectivos de las puertas de Sol y de la Luna, así como, entre otros, en el dorso del Monolito Bennett (Posnansky 1945, vol. II: figura 113a; Berenguer 2000: figura 35). ${ }^{20}$

\footnotetext{
20 Berenguer afirma: "El Personaje Frontal y los Rostros Frontales están sobre sendos pedestales escalerados, representaciones de las pirámides escalonadas que constituían el núcleo del poder y el ordenamiento dual del centro cívicoceremonial de Tiwanaku" (2000: 27, 34-35). El mismo autor además establece un paralelo entre la forma de la planta de la pirámide Akapana y el escalerado piramidal, pero lo asemeja a "la mitad de una cruz andina" (2000: 7).
} 


\section{El Escalerado Piramidal}

La iconografía no figurativa es quizás la de mayor dispersión geográfica; ya tuvimos oportunidad de analizar los diferentes tipos de escalerados piramidales, al igual que sus diversas posibilidades de combinación. Al mismo tiempo, ha quedado en evidencia que en la confección de bolsas anilladas del extremo sur del Perú y del extremo norte de Chile se emplearon similares criterios iconográficos, formales y técnicos.

En relación con los gorros tubulares hay que destacar el aspecto cronológico, ya que contamos con fechados por termoluminiscencia para los túmulos

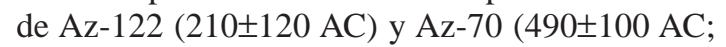
$70 \pm 200$ AC) (Muñoz 1987; Focacci y Erices 197273), dos de los sitios que han aportado evidencias de este tipo particular de gorro. Estas fechas son las más tempranas para dicho tipo, y la más tardía es 665 1100 DC para el cementerio Qui-84 (Agüero et al. 2001; Agüero y Cases 2004), lo cual ubica a este diseño como vigente entre aproximadamente 400 AC y 700 DC.

Por otra parte, este motivo - presumiblemente de gran fuerza simbólica- puede ser observado en la planta arquitectónica general de la plataforma aterrazada o pirámide Akapana reconstruida hipotéticamente por Manzanilla (1991: fig. 4), centro del culto y cosmogonía de Tiwanaku: en la forma de un escalerado piramidal de tres peldaños. Al respecto, también es muy sugerente la información aportada por Kolata (1993), así como la interpretación que hace de ella dicho autor: la cima de la pirámide Akapana se encontró cubierta por guijarros verdes provenientes de las quebradas del monte Quimsachata; en base a esto Kolata establece un interesante vínculo entre agua/ fuentes de agua y montaña, así como entre la pirámide y la representación simbólica de la montaña (Kolata 1993: 111). ${ }^{21}$

Al mismo tiempo, no olvidemos que el "Personaje Frontal con Cetros" en su versión arquetípica

21 Kolata expresa: "I believe that Akapana was conceived by the people of Tiwanaku specifically as their principal emblem of the sacred mountain. That is, Akapana served as a human-created simulacrum of the highly visible, natural mountain huacas in the Quimsachata range [...] The Akapana mimics the form of a mountain, ascending in seven steppedterraces to visually dominate the landscape" (1993: 111). de la Puerta del Sol se encuentra erguido sobre una plataforma escalerada, fundiéndose prácticamente con ella: no se le graficaron pies, de tal modo que las piernas entran directamente a la plataforma (lo mismo se puede apreciar en su representación del bloque de Llojeta y en las figuras de la misma deidad grabadas sobre el torso del Monolito Bennett) (Posnansky 1945, vol. II: figs. 60-61).

Por lo mismo, me parece necesario destacar el valor iconográfico del Escalerado Piramidal. Aun cuando posee forma tan claramente geométrica, y por tanto menos compleja que los diseños antropomorfos o zoomorfos, tras este motivo de peldaños en ascenso y descenso podemos intuir un significado tanto o más vigoroso que el de los otros iconos. Tomando en cuenta su frecuencia en los textiles formativos del área, tendremos que convenir en que su significado o valor simbólico no debe haber sido menor; tampoco parece que sea fruto de la casualidad que el "Personaje Frontal con Cetros" de la Puerta del Sol aparezca erguido precisamente sobre una plataforma piramidal de dos o tres peldaños, cuya forma general básica puede ser abstraída y abreviada en un diseño de Escalerado Piramidal.

En los Andes Centro-Sur desde tiempos inmemoriales se trabajó transformando cerros naturales en plataformas piramidales (es el caso de Cahuachi en el valle de Nasca), o construyendo plataformas escaleradas en formato de arquitectura monumental y de carácter ceremonial (es el caso de las pirámides del sitio Pukara, y también de la pirámide Akapana de Tiwanaku) (Mujica 1991; Manzanilla 1991; Manzanilla y Woodward 1990). El objetivo final era conferirle a una elevación natural o artificial la forma de cono truncado a modo de Escalerado Piramidal, reproduciendo quizás la forma majestuosa de las altas montañas, donde habitaban el o los dioses que controlaban las fuerzas naturales.

Por tanto, podemos suponer que durante el Formativo Tardío este icono -posible símbolo de las montañas y lugar de residencia del Personaje Frontal de Cabeza Radiada- parecería haber estado integrado al sistema simbólico de dicho personaje, pero no a su configuración estable, como unidad inseparable; por lo mismo, habría gozado al parecer de vida propia y cierta autonomía iconográfica como para figurar aisladamente del 
personaje mismo. Sólo más tarde, entre las manifestaciones del arte de Tiwanaku Clásico, encontraremos al Escalerado Piramidal como plataforma sobre la cual se yergue el "Personaje Frontal con Cetros", posiblemente representando no sólo la montaña, sino también la pirámide monumental, desde la cual dicha deidad ejercía su dominio.

\section{Conclusiones}

El examen de ciertas tapicerías de Azapa que presentan un icono de Cabeza Radiada nos ha permitido conectarlas con el Icono de Chorrillos y los taparrabos de Topater, así como con la pictografía del río Loa. Al mismo tiempo, el Icono de Chorrillos nos guió hasta el geoglifo del cerro Unitas y a otras manifestaciones del arte rupestre (Ariquilda, Tamentica y valle de Azapa); paralelamente, el Icono de Chorrillos también dirigió nuestros pasos hasta las láminas de oro de Guatacondo y Tulan. De forma análoga, pero en este caso siguiendo la huella del Escalerado Piramidal de las bandas inferiores de las túnicas de Azapa, es que dimos con la similar iconografía de ciertas bolsas malla y gorros tubulares. Al mismo tiempo, hemos podido constatar que tanto las túnicas con bandas inferiores en faz de trama, como las bolsas y gorros tubulares en técnica de anillado forman parte de la industria textil local, aun cuando los especímenes analizados correspondan por sus características iconográficas a un segmento más exclusivo dentro del mismo conjunto textil. A todas luces, los tejidos con ornamentación figurativa corresponden a una categoría textil especial, y probablemente debido a su carga simbólica hayan pertenecido a personajes destacados dentro de la comunidad, ya sean jefes étnicos o intermediarios frente a lo sobrenatural.

En conjunto, las evidencias aportadas por unos y otros soportes refuerzan a mi juicio la definición tentativa de lo que habría sido un sistema simbólico conocido ampliamente durante los siglos correspondientes a la fase tardía del Formativo chileno. El hecho de que tal sistema simbólico u horizonte iconográfico se haya basado en ideas o conceptos comunes y compartidos por un número indeterminado de diferentes grupos étnicos, no significa que las soluciones formales no hayan presentado aspectos particulares y regionales. Es muy probable que el horizonte iconográfico planteado para esta área tenga muchas otras variantes locales, que a su vez esperan por ser definidas.
Cada uno de los tres temas planteados no surge aisladamente, sino, por el contrario, se presentan interconectados; en ocasiones, unos ocupan el lugar de los otros, en diferentes combinaciones y adecuaciones, de modo tal, que creo factible plantear la idea de una iconografía unificadora para el período, que habría abarcado conceptos ideológicos de una vasta región que incluiría a las subáreas Valles Occidentales, Circumpuneña, Altiplano Meridional y Circumtiticaca.

Parece entonces plausible suponer la existencia de un "horizonte iconográfico" surandino, que resumiría elementos esenciales cosmológicos de la región entre $500 \mathrm{AC}$ y $600 \mathrm{DC}$, y que podría estar demostrando que el "Personaje Frontal con Cetros o Báculos" de Pukara y Tiwanaku y el Icono de Chorrillos del Formativo Tardío del norte de Chile -este último aparentemente inserto en una configuración menos estandarizada que no incluiría entre sus atributos a los clásicos cetros o báculos- habrían sido manifestaciones independientes del mismo concepto religioso fundamental.

Agradecimientos Agradezco en forma especial a Carolina Agüero el que me haya invitado a participar en la investigación que se encontraba dirigiendo (Proyecto FONDECYT 1990168), y que haya compartido sin reservas conmigo los resultados de la misma. También expreso mis agradecimientos a Pilar Alliende, por facilitarme el acceso a las bolsas anilladas de la colección del MCHAP; igualmente, me encuentro en deuda con Paulina Jélvez, quien compartió gentilmente conmigo el análisis de la bolsa anillada $\mathrm{n}^{\circ} 2765$ de la misma colección, que realizó en el Proyecto FONDECYT 1970110, titulado "El color en los textiles precolombinos de los Andes". Asimismo, agradezco a la conservadora Gabriela Alt, el que me haya facilitado fotografías del registro textil del sitio Topater, realizado en el marco del proyecto DIBAM "Preservación y Protección de las colecciones del Museo Arqueológico y Etnográfico Parque el Loa, Calama". Menciono además la gentileza de Carolina Agüero y Carole Sinclaire, quienes leyeron versiones previas de este trabajo aportando valiosos comentarios, y de Lautaro Núñez, quien me enviase una copia de una publicación suya sobre las láminas de Tulan. Tampoco podría dejar de mencionar la ayuda de Damon Peeler, quien tradujese el resumen de este artículo, y de Ann Peters, quien me facilitase fotografías e importantes detalles técnicos sobre las 
tapicerías del MASMA. Señalo además mi deuda de gratitud con Juan Chacama, quien no sólo me hizo saber del hallazgo de la pieza de Camarones, sino también me proporcionó fotografías de ella. Aprovecho además la ocasión para agradecer a Oscar Espoueys por el apoyo brindado durante muchos años, quien esta vez me hizo lle- gar la fotografía del grabado del cerro Chuño. Deseo a la vez expresar mis agradecimientos a las bibliotecarias del MCHAP, Marcela Enríquez e Isabel Carrasco, por la excelente disposición que siempre ofrecen en la búsqueda bibliográfica, pilar fundamental de cualquier investigación.

\section{REFERENCIAS CITADAS}

AGÜERO, C., 1994. Madejas, hilados y pelos: Los turbantes del Formativo Temprano en Arica, norte de Chile. Tesis para optar al título de Arqueólogo. Depto. de Antropología, Facultad de Ciencias Sociales, Universidad de Chile, Santiago.

-1995a. Indicadores textiles de grupos formativos: Proposición de una tipología de turbantes. Hombre y Desierto 9: 97-111.

_ 1995b. El cementerio "Protonazca" de Pisagua (D), colección Max Uhle. (II) Estudio de la textilería. Hombre y Desierto 9: 7-20.

2000. Tarapacá-40 y la textilería formativa del norte de Chile. Actas de la XIII Reunión Anual del Comité Nacional de Conservación Textil, pp. 7-18. Arica.

-2002. Textilería de Los Aborígenes de Arica: La colección Uhle del Museo Nacional de Historia Natural (Santiago de Chile). Gaceta Arqueológica Andina 26: 171-191.

AGÜERO, C. y B. CASES, 2000 Ms. Los textiles formativos del norte de Chile. Informe Proyecto FONDECYT $N^{\circ} 1990168$, Santiago.

-2004. Quillagua y los textiles formativos del Norte Grande de Chile. Chungara, volumen especial, pp. 59-77.

AGÜERO, C. y H. HORTA, 1997 Ms. Los textiles del Período Intermedio Tardío del valle de Azapa y costa de Arica. Informe Final Textil del Proyecto FONDECYT 1960113, Santiago.

AGÜERO, C., M. URIBE y O. REYES, 1995. Nuevos sitios para la ocupación formativa del valle de Quillagua. Boletín de la Sociedad Chilena de Arqueología 21: 24-27.

AGÜERO, C., M. URIBE, P. AYALA, B. CASES y C. CARRASCO, 2001. Ceremonialismo del Período Formativo en Quillagua, Norte Grande de Chile. Boletín de la Sociedad Chilena de Arqueología 32: 24-34.

ALLISON, M., B. ARRIAZA, V. STANDEN, G. FOCACCI, M. RIVERA y J. LOWESTEIN, 1984. Chinchorro, momias de preparación complicada: Métodos de preparación. Chungara 13: 155-173.
ARRIAZA, B., 1994. Tipología de las momias Chinchorro y evolución de las prácticas de momificación. Chungara 26: 11-24.

BERENGUER, J., 2000. Tiwanaku. Señores del lago sagrado. Museo Chileno de Arte Precolombino-Banco Santiago, Santiago.

BERENGUER, J., V. CASTRO, C. ALDUNATE, L. CORNEJO y C. SINCLAIRE, 1985. Secuencia del arte rupestre en el Alto Loa: Una hipótesis de trabajo. En Estudios en Arte Rupestre, C. Aldunate, J. Berenguer y V. Castro (Eds.), pp. 87-108. Museo Chileno de Arte Precolombino, Santiago.

BIRD, J., 1943. Excavations in Northern Chile. Anthropological Papers, vol. 38: 173-318. American Museum of Natural History, Nueva York.

BITTMANN, B., 1985. Reflections on geoglyphs from Northern Chile. Latin American Studies, I. H.B.C. Publications, Rickmanworth.

BITTMANN, B. y J. MUNIZAGA, 1979. El arco en América: Evidencia temprana y directa de la cultura Chinchorro (norte de Chile). Indiana 5: 229-251.

BOUYSSE-CASSAGNE, T., 1988. Lluvias y cenizas. Dos Pachacuti en la historia. HISBOL, La Paz.

CARTAJENA, I., 1994. Determinación de restos óseos de camélidos en dos yacimientos del Loa Medio (II Región). Estudios Atacameños 11: 25-52.

CASES, B., 1999. Textiles formativos de la cuenca del Loa y de Atacama. Actas de la XIII Reunión Anual del Comité Nacional de Conservación Textil, pp. 35-43. Arica.

COOK, A., 1994. Wari y Tiwanaku: Entre el estilo y la imagen. Pontificia Universidad Católica del Perú, Fondo Editorial, Lima.

CHACAMA, J. y L. BRIONES, 1996. Arte rupestre en el desierto tarapaqueño, norte de Chile. Boletín SIARB 10: 41-51.

CHACAMA, J. e I. MUÑOZ, 1991. La cueva de La Capilla: Manifestaciones de arte y símbolos de los pescadores arcaicos de Arica. Actas del XI Congreso Nacional de Arqueología Chilena, T. I: 37-41. Santiago. 
CHAVEZ, S., 1975. The Arapa and Thunderbolt Stelae: A case of stylistic identity with implications for Pucara influences en the area of Tiahuanaco. Nawpa Pacha 13: 3-26.

1984/85. Funerary offerings from a Middle Horizon context in Pomacanchi, Cuzco. Ñawpa Pacha 22/23: 1-48.

CHAVEZ, S. y K. L. MOHR CHAVEZ, 1975. A carved stela from Taraco, Puno, Perú, and the definition of an early style of stone sculpture from the altiplano of Perú and Bolivia. Ñawpa Pacha 13: 45-84.

DAUELSBERG, P., 1963. Complejo Faldas del Morro. Actas del Encuentro Internacional de Arqueología de San Pedro de Atacama, pp. 200-202. Antofagasta.

-1985. Faldas del Morro: Fase cultural agroalfarera temprana. Chungara 14: 7-44.

DELEONARDIS, L., 2000. The body context: Interpreting Early Nasca decapitated burials. Latin American Antiquity 11 (4): 363-386

FOCACCI, G. y S. ERICES, 1972/73. Excavaciones en túmulos de San Miguel de Azapa (Arica, Chile). Actas del VI Congreso de Arqueología Chilena, 47-62. Santiago.

1980. Síntesis de la arqueología del extremo norte de Chile. Chungara 6: 3-23.

FOCACCI, G. y S. CHACON, 1989. Excavaciones arqueológicas en los faldeos del Morro de Arica. Sitios Morro 1/6 y 2/2. Chungara 22: 15-62.

GALLARDO, F., 1993. La sustancia privilegiada: Turbantes, poder y simbolismo en el Formativo del norte de Chile. En Identidad y prestigio en los Andes. Gorros, turbantes $y$ diademas, J. Berenguer (Ed.), pp. 9-15. Museo Chileno de Arte Precolombino, Santiago.

GALLARDO, F., C. SINCLAIRE y C. SILVA, 1999. Arte rupestre, emplazamiento y paisaje en la cordillera del Desierto de Atacama. En Arte rupestre en los Andes de Capricornio, J. Berenguer y F. Gallardo (Eds.), pp. 5796. Museo Chileno de Arte Precolombino-Banco Santander, Santiago.

GISBERT, T., 1980. Iconografía y mitos indígenas en el arte. Gisbert y Cía. S.A. Libreros Editores, La Paz.

GOLDSTEIN, P., 1995/96. Tiwakanu settlement patterns of the Azapa Valley, Chile. New Data, and the legacy of Percy Dauelsberg. Diálogo Andino 14/15: 57-73.

HAEBERLI, J., 2001. Tiempo y tradición en Arequipa, Perú, y el surgimiento de la cronología del Tema de la Deidad Central. Boletín de Arqueología PUCP 5: 89-137.

HORTA, H., 1997. Estudio iconográfico de textiles arqueológicos del valle de Azapa, Arica. Chungara 29 (1): 81-108.

1999 Ms. Presencia de inkuñas en cementerios de costa y valle (Arica), durante el Período Intermedio Tardío. Ponencia presentada en la XIII Reunión del Comité Nacional de Conservación Textil, Arica. _2001a. Diademas de plumas en entierros de la costa del norte de Chile: ¿Evidencias de la vestimenta de una posible parcialidad pescadora? Chungara 32 (2): 235-243.

_ 2001b. Identificación tentativa de la voluta "S": Motivo decorativo de textiles arqueológicos de Arica, norte de Chile. Segundas Jornadas de Arte y Arqueología, J. Berenguer, L. Cornejo; F. Gallardo y C. Sinclaire (Eds.) pp. 2-14. Museo Chileno de Arte Precolombino, Santiago.

HORTA, H. y J. BERENGUER, 1995. Un icono formativo en el arte rupestre del Alto Loa. Boletín de la Sociedad Chilena de Arqueología 20: 23.

KNOBLOCH, J. P., 2000. Wari ritual power at Conchopata: An interpretation of Anadenanthera colubrina iconography. Latin American Antiquity 11 (4): 387-402.

KOLATA, A., 1993. The Tiwanaku: Portrait of an Andean civilization. Blackwell Publishers, Cambrigde.

LATCHAM, R., 1938. Arqueología de la región atacameña. Prensas de la Universidad de Chile, Santiago.

LUMBRERAS, L., 1981. Arqueología de la América Andina. Editorial Milla Batres, Lima.

MANZANILLA, L., 1991. Akapana. Una pirámide en el centro del mundo. Instituto de Investigaciones Antropológicas, UNAM, México D. F.

MANZANILLA, L. y E. WOODARD, 1990. Restos humanos asociados a la pirámide de Akapana (Tiwanaku, Bolivia). Latin American Antiquity 1 (2): 133-149.

MEIGHAN, C., 1980. Archaeology of Guatacondo, Chile. Prehistoric trails of Atacama: Archaeology of Northern Chile. En Monumenta Archaeologica 7. C. W. Meighan y D. L. True (Eds.), pp. 99-126. The Institute of Archaeology, University of California, Los Angeles.

MORAGAS, C., 1982. Túmulos funerarios en la costa sur de Tocopilla (Cobija), II Región. Chungara 9: 152-173.

- 1995. Desarrollo de las comunidades prehispánicas del litoral Iquique-desembocadura río Loa. Actas del XIII Congreso Nacional de Arqueología Chilena, T. II: 6380. Antofagasta.

MUJICA, E., 1985. Altiplano-coast relationships in the SouthCentral Andes: From indirect to direct complementarity. En Andean ecology and civilization, S. Masuda, I. Shimada y C. Morris (Eds.), pp. 103-140. University of Tokyo Press, Tokyo.

1991. Pukara: Una sociedad compleja temprana en la cuenca norte del Titicaca. En Los incas y el antiguo Perú: 3000 años de historia. Catálogo de exhibición del Centro Cultural de la Villa de Madrid. Sociedad Estatal Quinto Centenario-Lunwerg Editores S. A., Madrid.

MUJICA, E., M. RIVERA y T. LYNCH, 1983. Proyecto de estudio sobre la complementariedad económica Tiwanaku en los Valles Occidentales del Centro-Sur Andino. Chungara 11: 85-109. 
MUÑOZ, I., 1980. Investigaciones arqueológicas en los túmulos funerarios del valle de Azapa. Chungara 6: 57-95.

_ 1983a. La Fase Alto Ramírez del extremo norte de Chile (valle-costa). En Asentamientos aldeanos en los valles costeros de Arica. Documentos de Trabajo 3: 3-42. Universidad de Tarapacá, Arica.

_ 1983b. El poblamiento aldeano en el valle de Azapa y su vinculación con Tiwanaku (Arica, Chile). En Asentamientos aldeanos en los valles costeros de Arica. Documentos de Trabajo 3: 43-94. Universidad de Tarapacá, Arica.

1987. Enterramientos en túmulos en el valle de Azapa: Nuevas evidencias para definir la Fase Alto Ramírez en el extremo norte de Chile. Chungara 19: 93-127.

_ 1989. El Período Formativo en el Norte Grande. En Culturas de Chile. Prehistoria. Desde sus orígenes hasta los albores de la conquista, J. Hidalgo, V. Schiappacasse, H. Niemeyer, C. Aldunate e I. Solimano (Eds.), pp. 107-128. Editorial Andrés Bello, Santiago.

_- 1995/96. Poblamiento humano y relaciones interculturales en el valle de Azapa: Nuevos hallazgos en torno al Período Formativo y Tiwanaku. Diálogo Andino 14/15: 241-277.

MUÑOZ, I., R. ROCHA y S. CHACON, 1991. Camarones 15: Asentamiento de pescadores correspondiente al Período Arcaico y Formativo en el extremo norte de Chile. Actas del XI Congreso Nacional de Arqueología Chile$n a$, T. II: 1-24. Santiago.

NUÑEZ, L., 1967. Sobre los complejos culturales Chinchorro y Faldas del Morro del norte de Chile. Rehue 2: 111-142.

-1970. Algunos problemas del estudio del complejo arqueológico Faldas del Morro, norte de Chile. En Abband. berich. des Staa. Mus. volker. Dresden Bond 31, Berlin.

-1971. Secuencia y cambio en los asentamientos humanos de la desembocadura del río Loa en el norte de Chile. Boletín de la Universidad de Chile 112: 3-25.

-1976. Geoglifos y tráfico de caravanas en el desierto chileno. En Homenaje al Dr. Gustavo Le Paige, pp. 147201. Universidad del Norte, Antofagasta.

- 1982. Temprana emergencia de sedentarismo en el desierto chileno. Proyecto Caserones. Chungara 9: 80-122.

-1984a. Pircas: Ocupación temprana en el norte de Chile. Gaceta Arqueológica Andina 11: 8, 9 y 12.

_ 1984b. El asentamiento Pircas: Nuevas evidencias de tempranas ocupaciones agrarias en el norte de Chile. Estudios Atacameños 7: 152-177.

-1989. Hacia la producción de alimentos y la vida sedentaria (5000 AC-900 DC). En Culturas de Chile. Prehistoria. Desde sus orígenes hasta los albores de la Conquista, J. Hidalgo, V. Schiappacasse, H. Niemeyer, C.
Aldunate e I. Solimano (Eds.), pp. 81-105. Editorial Andrés Bello, Santiago.

1992. Fase Tilocalar: Nuevas evidencias formativas en la Puna de Atacama (norte de Chile). En Formativo sudamericano, una reevaluación, P. Ledergerber-Crespo (Ed.), pp. 227-242. Abya-Yala, Cuenca.

-1994. Emergencia de complejidad y arquitectura jerarquizada en la Puna de Atacama: Las evidencias del sitio Tulan-54. En Taller de Costa a Selva: Producción e intercambio en los pueblos agroalfareros de los Andes Centro-Sur, M. E. Albeck (Ed.), pp. 85-115. Instituto Interdisciplinario Tilcara, Buenos Aires.

NUÑEZ, L. y T. DILLEHAY, 1978. Movilidad giratoria, armonía social y desarrollo en los Andes meridionales: Patrones de tráfico e interacción económica. Universidad del Norte, Antofagasta.

NUÑEZ, L. y C. MORAGAS, 1977. Ocupación con cerámica temprana en la secuencia del distrito Cáñamo (costa desértica del norte de Chile). Estudios Atacameños 5: 21-49.

PALMA, J., C. PRADO y M. DE LOS A. VILLASECA, 1995. Aporte metodológico al estudio de la cestería arqueológica. Actas del XIII Congreso de Arqueología Chilena, pp. 157-164. Antofagasta.

PORTUGAL, M., 1957. Arqueología de La Paz. Arqueología Boliviana ( $1^{\mathrm{a}}$ Mesa Redonda), Biblioteca Paceña, La Paz.

POSNANSKY, A., 1945. Tiahuanacu: La cuna del hombre americano. T. I. Ministerio de Educación, La Paz.

REINHARD, J., 1983. Las líneas de Nazca. Montañas y fertilidad. Boletín de Lima 26: 29-50.

- - 1991. Tiwanaku: Ensayo sobre su cosmovisión. Pumapunku 2: 82-97.

RIVERA, M., 1974. Una hipótesis sobre movimientos poblacionales altiplánicos y transaltiplánicos a las costas del norte de Chile. Chungara 5: 7-30.

-1975. Aspectos sobre el desarrollo tecnológico en el proceso de agriculturación en el norte prehispano, especialmente Arica. Chungara 3: 79-107.

_-1976. Nuevos aportes sobre el desarrollo cultural altiplánico en los valles bajos del extremo norte de Chile, durante el Período Intermedio Temprano. En Homenaje al Dr. Gustavo Le Paige, pp. 71-82. Universidad del Norte, Antofagasta.

—_ 1980. Algunos fenómenos de complementariedad económica a través del Area Centro Sur Andina. La fase Alto Ramírez reformulada. En Temas Antropológicos del Norte de Chile, M. Rivera (Ed.), pp. 71-103. Universidad de Chile, Antofagasta.

-1984. Altiplano and tropical lowland contacts in Northern Chile prehistory. Chinchorro and Alto Ramírez revisited. En Social and economic organization in the prehispanic 
Andes, D. Browman, R. Burger y M. Rivera (Eds.). pp. 143-160. BAR Int. Series 194, Oxford.

-1987. Tres fechados radiométricos de Pampa Alto Ramírez, norte de Chile. Chungara 18: 7-13.

1995. Comentario sobre un icono formativo en arte rupestre del Alto Loa. Boletín de la Sociedad Chilena de Arqueología 21: 20-21.

RIVERA, M., P. SOTO, L. ULLOA y D. KUSHNER, 1974. Aspectos sobre el desarrollo tecnológico en el proceso de agriculturización en el norte prehispano, especialmente Arica (Chile). Análisis textil de restos del Laucho, Chinchorro, Faldas del Morro y Alto Ramírez. Chungara 3: 79-107.

RIVERA, M., D. SHEA, A. CAREVIC y G. GRAFFAM, 1995/96. En torno a los orígenes de las sociedades complejas andinas: Excavaciones en Ramaditas, una aldea formativa del Desierto de Atacama. Diálogo Andino 14/15: 205-239.

ROWE, H. J., 1976. El arte religioso del Cuzco en el Horizonte Temprano. Ñawpa Pacha 14: 1-20.

ROWE, H. J. y C. T. BRANDEL, 1969. Pucara style pottery designs. Ñawpa Pacha 16: 1-16.

SANTORO, C., 1980. Estratigrafía y secuencia cultural funeraria. Fases: Azapa, Alto Ramírez y Tiwanaku (AricaChile). Chungara 6: 24-45.

1981. Formativo temprano en el extremo norte de Chile. Chungara 8: 33-62.

SANTORO, C. y P. DAUELSBERG, 1985. Identificación de indicadores tempoculturales en el arte rupestre del extremo norte de Chile. En Estudios en arte rupestre, C. Aldunate, J. Berenguer y V. Castro (Eds.), pp. 69-86. Museo Chileno de Arte Precolombino, Santiago.

SANTORO, C. y L. ULLOA, 1985. Culturas de Arica. Serie Patrimonio Cultural Chileno, Santiago.
SANTORO, C., V. STANDEN y B. ARRIAZA, 2001. ¿Patrón funerario arcaico o alteración postdeposicional? El enterratorio de Patapatane en los Andes Centro Sur. Chungara 33/1: 43-49.

SCHIAPPACASSE, V. y H. NIEMEYER, 1963. Investigaciones arqueológicas en las terrazas de Conanoxa, valle de Camarones (Prov. de Tarapacá). Revista Universitaria, año XLVIII: 101-166.

_ 1969. Comentario a tres fechas radiocarbónicas de sitios arqueológicos de Conanoxa (valle de Camarones, Prov. de Tarapacá). Noticiario Mensual del Museo Nacional de Historia Natural 151, año XIII.

SINCLAIRE, C., 1997. Pinturas rupestres y textiles formativos en la región atacameña: Paralelos iconográficos. Estudios Atacameños 14: 327-338.

SOTO-HEIM, P., 1987. Evolución de deformaciones intencionales, tocados y prácticas funerarias en la prehistoria de Arica, Chile. Chungara 19: 129-214.

STANDEN, V. y L. NUÑEZ, 1984. Indicadores antropológicos físicos y culturales del cementerio precerámico Tiliviche2 (norte de Chile). Chungara 12: 175-185.

THOMAS, C., A. BENAVENTE, I. CARTAJENA y G. SERRACINO, 1995. Topater, un cementerio temprano: Una aproximación simbólica. Hombre y Desierto 9: 159-172.

ULLOA, L., 1982. Evolución de la industria textil prehispánica en la zona de Arica. Chungara 8: 97-136.

YACOBACCIO, H., C. MADERO, M. del C. REIGADAS, 2001. Inhumación de una cabeza aislada en la puna argentina. Chungara 33/1: 79-82.

ZLATAR, V., 1984. Cementerio prehispánico Pica-8. Universidad de Antofagasta, Chile.

ZORN, E., 1987. Un análisis de los tejidos en los atados rituales de los pastores. Revista Andina 5: 489-525. 